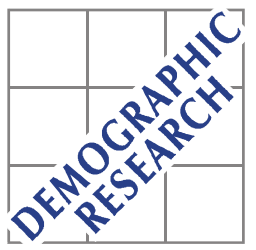

Demographic Research a free, expedited, online journal

of peer-reviewed research and commentary in the population sciences published by the Max Planck Institute for Demographic Research

Konrad-Zuse Str. 1, D-18057 Rostock · GERMANY

www.demographic-research.org

DEMOGRAPHIC RESEARCH

VOLUME 19, ARTICLE 16, PAGES 503-556

PUBLISHED 01 JULY 2008

http://www.demographic-research.org/Volumes/Vol19/16/

DOI: 10.4054/DemRes.2008.19.16

Research Article

France:

High and stable fertility

Laurent Toulemon

Ariane Pailhé

\title{
Clémentine Rossier
}

This publication is part of Special Collection 7: Childbearing Trends and Policies in Europe (http://www.demographic-research.org/special/7/)

(C) 2008 Toulemon, Pailhé \& Rossier.

This open-access work is published under the terms of the Creative Commons Attribution NonCommercial License 2.0 Germany, which permits use, reproduction \& distribution in any medium for non-commercial purposes, provided the original author(s) and source are given credit. See http:// creativecommons.org/licenses/by-nc/2.0/de/ 


\section{Table of Contents}

$\begin{array}{lll}1 & \text { Introduction } & 504\end{array}$

$2 \quad$ Fertility levels and trends 507

2.1 Fertility is stable in France at roughly 2 children per woman 507

$2.2 \quad$ Population forecast for the next fifty years: heading towards a 508 stationary population

$2.3 \quad$ Ageing of fertility 509

2.4 Cohort fertility assumed to remain stable in future 512

$2.5 \quad$ Fertility by parity 514

2.6 Educational differentials in fertility are small and decreasing $\quad 519$

$\begin{array}{ll}2.7 & \text { Immigrant and native fertility }\end{array}$

3 Changes in family behaviour since the 1970s 524

$3.1 \quad$ Decline of marriage $\quad 524$

$\begin{array}{ll}3.2 & \text { Contraceptive use and abortion } \\ 527\end{array}$

$4 \quad$ Female and youth participation in the labour force 531

4.1 Impact of 1994 child care allowance reform on fertility and 531

4.2 Economic situation of young adults $\quad 534$

4.3 Age and gender inequalities in unemployment and wages 534

$4.4 \quad$ Gender roles within family $\quad 535$

$5 \quad$ Social and population policies $\quad 536$

5.1 Current consensus $\quad 536$

5.2 Mix of tools 538

5.3 Effect of family policies on fertility 541

5.4 Other current demographic questions 543

$6 \quad$ Attitudes towards childbearing in France 543

6.1 Fertility intentions 544

6.2 'Family cultural divide' runs through France 545

7 Conclusion $\quad 546$

$\begin{array}{ll}\text { References } & 547\end{array}$

$\begin{array}{ll}\text { Appendix } & 554\end{array}$ 


\title{
France: \\ High and stable fertility
}

\author{
Laurent Toulemon ${ }^{1}$ \\ Ariane Pailhé2 \\ Clémentine Rossier ${ }^{3}$
}

\begin{abstract}
The current total fertility rate in France is around 1.9 children per woman. This is a relatively high level by current European standards and makes France an outlier, despite the fact that its other demographic trends, especially conjugal behaviour, and social and economic trends are not very different from other Western European countries. France can serve as a counterfactual test case for some of the hypotheses advanced to explain the current low level of fertility in most European countries (delay in fertility, decline in marriage, increased birth control, greater economic uncertainty). France's fertility level can be partly explained by its active family policy introduced after the Second World War, and adapted in the 1980s to accommodate women's entry into the labour force. This policy is the result of a battle, fuelled by pro-natalism, between the conservative supporters of family values and the promoters of state-supported individual equality. French family policy thus encompasses a wide range of measures based on varying ideological backgrounds, and it is difficult to classify in comparison to the more precisely focused family policies of other European welfare states. The active family policy seems to have created especially positive attitudes towards two- or three child families in France.
\end{abstract}

\footnotetext{
${ }^{1}$ Institut national d'études démographiques (INED).E-mail: toulemon@ined.fr

${ }^{2}$ Institut national d'études démographiques (INED). E-mail: pailhe@ @ined.fr

${ }^{3}$ Institut national d'études démographiques (INED). E-mail: Clementine.rossier@ined.fr
} 


\section{Introduction}

The Total Fertility Rate (TFR) has remained almost stable in France since 1975 at around 1.8 children per woman, with a slight decrease in the early 1990s and a slight increase since 1996. Central population forecasts, based on stable fertility and migration at 2005 levels, predict stability of the population aged 60 and below, and an increase in the population aged over 60 . The timing of fertility is rapidly changing in France: The age at first birth has risen since the early 1970s to reach 27.7 years in 2005 . However, fertility rates also increased after age 30 during this period, so that women born after 1970 are expected to have, on average, 2.0 children each. Period parity progression ratios have remained stable since 1975 (except for the probability of having a first child, which is affected by the timing of fertility). The stable level of fertility is thus accompanied by a stable distribution of family sizes. Women of higher educational attainment have fewer children on average, but when they do have them, they are more likely to have three children than women of medium educational level. Overall, social differentials are small in comparison with the rest of Europe, and they have decreased over the $20^{\text {th }}$ century. The fertility of immigrants contributes little to the level of fertility in France (Prioux 2005; Toulemon 2003; Toulemon 2006).

The French level of period fertility, which is the highest in the European Union, is somewhat puzzling. As elsewhere on the continent, entry into parenthood has been delayed. French young men and women have increased their investment in education and delayed their entry into the labour market. Entering the labour market is particularly difficult in France, and unemployment rates are high among young people (Chambaz 2001). As in the rest of Western Europe, sexual relations and reproduction have increasingly occurred outside of marriage since the late 1960s, which is roughly the time at which the use of contraception and abortion was legalized. Divorce rates have also increased since the early 1970s, and the proportion of extra-marital births in France is today one of the highest in Europe, as is the use of reversible contraception and abortion. As in other European countries, rates of female participation in the labour force started to increase in the 1970s and today most French women work. Although fathers now spend more time with their children, the division of labour between men and women remains fairly unequal and most childcare still falls to women. In terms of the division of domestic labour, France occupies an intermediate position in Europe (Eurostat 2006b; Aliaga, 2006).

As we show in this chapter, France has maintained a relatively high level of fertility, despite all these social and demographic changes (delayed entry into adulthood, increased couple instability, more births outside marriage, greater birth control, and increased female participation in the labour force), and despite some resistance to gender equality (only modest progress in the division of tasks between 
men and women). The case of France thus invalidates the two most commonly held explanations of low fertility. The first explanation is that low fertility is related to the delay in entry into parenthood. "The fertility-inhibiting effect of the rising age at childbearing is primarily responsible for the fact that observed fertility is below replacement" (Bongaarts 2001, p. 275). Kohler and Ortega agree with Bongaarts: "The postponement of fertility is not neutral with respect to the quantum of fertility" (2006, p. 25), and so do Morgan and Taylor in their recent review of the literature in the field of research: "Work focusing on the timing of parenthood shows the many ways that timing and number are interrelated" (2006, p. 9). Demographic trends in France do not follow the suggested pattern, that delaying entry into parenthood results in lower fertility. The second explanation of low fertility relates this trend to the individuation process and its obvious correlate, the breakdown of traditional family forms. On the basis of empirical work that explores the link between varied attitudinal scales and demographic outcomes, Lesthaeghe and Surkyn conclude: "Union formation, transition to parenthood and further family building [are all] associated [...] negatively with indicators of the individuation process" (1988, p. 40). They echo the conclusion of Van de Kaa, who describes a second demographic transition, marked by "the transition to individualism [which] appears to have led to an extended period of below-replacement fertility" (1987, p. 52). However, it is now clear that greater individual freedom, in the field of matrimony in particular, is not linked to fertility outcomes, at least not at the aggregate level. Kohler and Ortega (2006), show that a positive relation between divorce rates and fertility prevails today in Europe, including France.

The most obvious explanation for France's relatively high fertility is its particularly active family policy. Family policy was already on the political agenda at the end of the $19^{\text {th }}$ century and began to be implemented shortly after the Second World War. This long history of considering family policy enabled the government to react swiftly to women's entry into the labour force, by designing new policy measures. Today's policy is the result of a century-long battle, fuelled by pronatalism, between the conservative supporters of family values and the promoters of state-supported individual equality. French family policy thus includes a wide range of measures based on a variety of ideological standpoints.

Because of the variegated nature of its family policy, France does not fit easily into the classification of Western welfare systems. As Caldwell and Schindlmayr (2003, p.255) put it, 'France remains a problem for the model builders'. Esping-Andersen $(1990,1999)$ divides European countries into four groups according to the intentions and organization of their welfare system. The Nordic countries have universalistic state policies that promote the independence of individuals and social equality; the state provides most of the welfare (welfare state). English-speaking countries promote market-based individualism; families and the market provide the welfare (liberal 
welfare states). Central European countries (including France and Germany) have policies geared at preserving the status quo and traditional family forms; they depend mostly on the family to provide welfare (conservative welfare state). Mediterranean countries are like conservative states, but have a stronger family bias (SouthernEuropean welfare state).

Feminist researchers consider the interaction of two types of relations within the family, partnership and parenthood, when classifying European welfare policies (Neyer 2003). Gornick, Meyers, and Ross (1997) focus on the impact of social policies on female employment. They group France, Belgium, Denmark, Finland and Sweden as countries where social policies help women to remain in the labour force. In Germany, the Netherlands, and Italy, family policies force women to exit the labour force until their children go to school. In the United Kingdom, there is limited support, and the ability of mothers to stay in the labour force depends on individual capacities. Anttonen and Sipila (1996) distinguish different types of state child care policies: the Scandinavian model (universal policies aimed at promoting gender equality); the Southern model (limited supply of state care services); France and Belgium, with extensive state support to families but no support for gender equality; Netherlands and Germany, where childcare is still provided by parents who benefit from state support schemes; and the British systems, in which state help is mostly directed towards 'problem cases'.

Hantrais (2004) places the relation between family and state into three categories. The Nordic and French-speaking countries are 'defamilialised' (strong state support for the care of family members); the English- and German-speaking countries and the Netherlands are 'partially familialised'; the Southern countries are 'familialised'. McDonald (2005), simplifying matters even further, defines two groups of countries. The first includes the countries of Southern Europe and the German-speaking European countries where "there is a strong, traditional value that family and state are separate entities and that families should support their own members" (p. 11) and where fertility levels are below 1.5 children per women. The other group includes all the Englishspeaking, Nordic, French- and Dutch-speaking countries, where gender equality is higher, there are family-friendly institutional arrangements, and fertility levels are higher than 1.5.

All of the above authors are right, as will be seen from the description in this chapter of the multi-facetted French family policy. Cross-national comparisons are made difficult by the numerous specificities of each country, but in France, this multifacetted family policy and positive attitudes towards fertility fuelled by it probably explains, in great part, its current relatively high fertility level compared to other European countries. 


\section{Fertility levels and trends}

\subsection{Fertility is stable in France at roughly 2 children per woman}

The current fertility level is high in France ${ }^{4}$, by European standards. In 2005, the provisional estimate of the TFR was 1.92 children per woman (Figure 1). Since 1975, the TFR has been almost stable at around 1.8 children per woman, with a slight decrease in the early 1990s and a slight increase since 2000.

Due to the change in the age of the mother at childbirth, the usual TFR leads to a fertility level estimate that is lower than those produced from more sophisticated indices that take into account the parity distribution of women and order of births, as well as the duration between births (Rallu and Toulemon 1994). The index that takes into account birth order and, for births of order 2 and over, duration since last birth, (Parity and Duration Total Fertility Rate, PDTFR, also called Period Average Parity, PAP), gives a more consistent estimate of period fertility (Toulemon and Mazuy 2001; Sobotka et al. 2005). Its level in France is around 2.0 children per woman, close to the cohort total fertility of corresponding cohorts (Figure 1). Accurate data are not available to estimate its value since 1999, but it is probably close to or above 2.1 children per woman.

The current level of cohort fertility seems similar to that of cohorts born around 1900 , but the number of surviving children is much higher. Infant mortality was very high a century ago. Nine percent of children born to women who were born in 1900 died during their first year of life, while the infant mortality rate is now less than 5 per thousand $(0.5 \%)$. For women born in 1965, the French cohort total fertility (2.03) is among the highest in Europe, the highest being Ireland at 2.18, and is close to the levels in Norway (2.06) and Sweden (1.98). The cohort TFR could stabilize at 2.0 children per woman, and it is unlikely that it will fall below the level of 1.9 , the current level of period TFR (Prioux 2005).

\footnotetext{
${ }^{4}$ This chapter deals with mainland France, excluding the overseas départements. Thus, some figures might differ slightly from the official estimates published by the National Institute of Statistics (INSEE), e.g. the total fertility rate is estimated at 1.92 as against 1.94 children per woman, the number of births in 2005 as 775,000 instead of 807,000 , etc.
} 
Figure 1: $\quad$ Fertility since 1900 in France

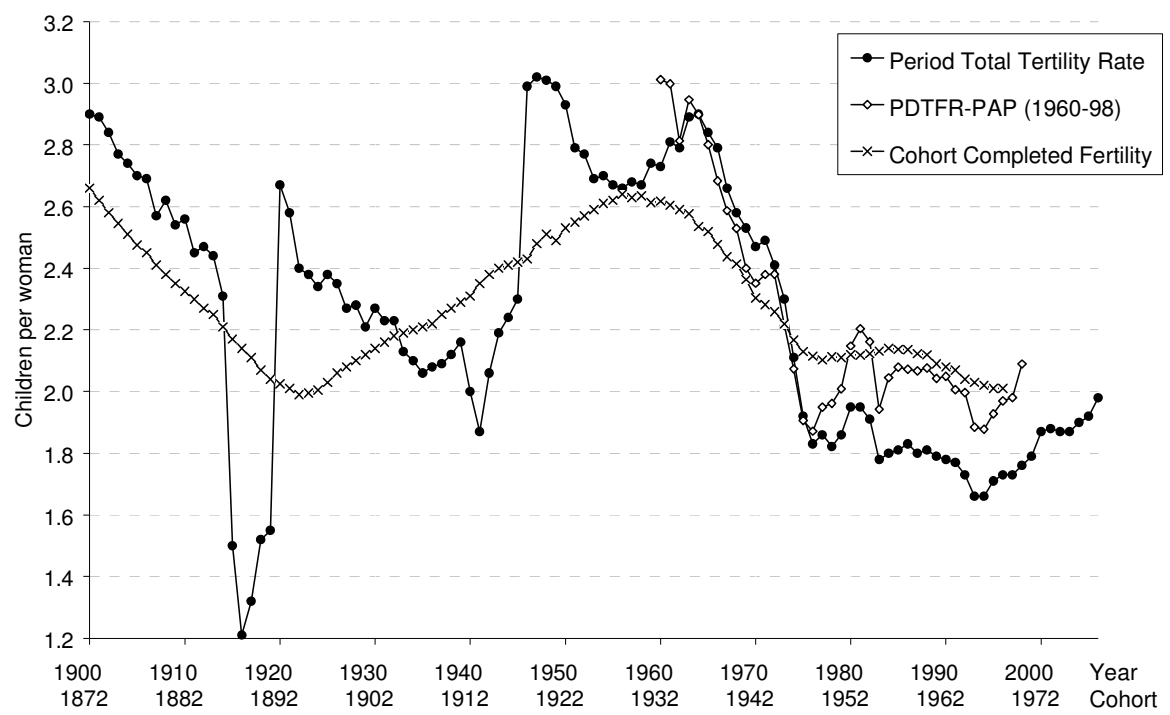

Sources: INSEE, civil registration data. Daguet, 2002; INSEE, 2007; Toulemon, Mazuy, 2001

\subsection{Population forecast for the next fifty years: heading towards a stationary population}

This fertility figure is close to the 'replacement level' of 2.1 children per woman. In fact, France is currently experiencing a small net migration that adds to fertility. The current level of 100,000 net migrants per year is small by European standards: In 2005, the net migration rate was 1.6 per thousand, compared with a natural increase of 4.1 , as against 3.7 and 0.7 respectively for the European Union as a whole (Eurostat 2006a). Nevertheless, this net migration is virtually equivalent to a surplus of 75,000 births leading to adults of reproductive age, and net reproduction at age 30, taking into account mortality and migration (Daguet 2002), is equal to one daughter per woman.

Thus, the central population forecast, based on the stability of fertility and migration at current levels, predicts stability in the population aged 60 or less, while the population aged 60 and over will increase as a consequence of the baby boom that took place 60 years ago (Figure 2). The number of births is assumed to remain constant at around 750,000 . The number of deaths will increase, due to large cohorts of baby 
boomers reaching the end of their lifespan (Robert-Bobée 2006). Even in the very long run, when the baby boomers are dead, the population would remain quasi-stationary, with a constant population by age up to age 60 , and a slightly increasing population at older ages if mortality goes on decreasing.

Figure 2: $\quad$ Age pyramid in France in 2005 and 2050, under medium population projection scenario (constant fertility and migration)

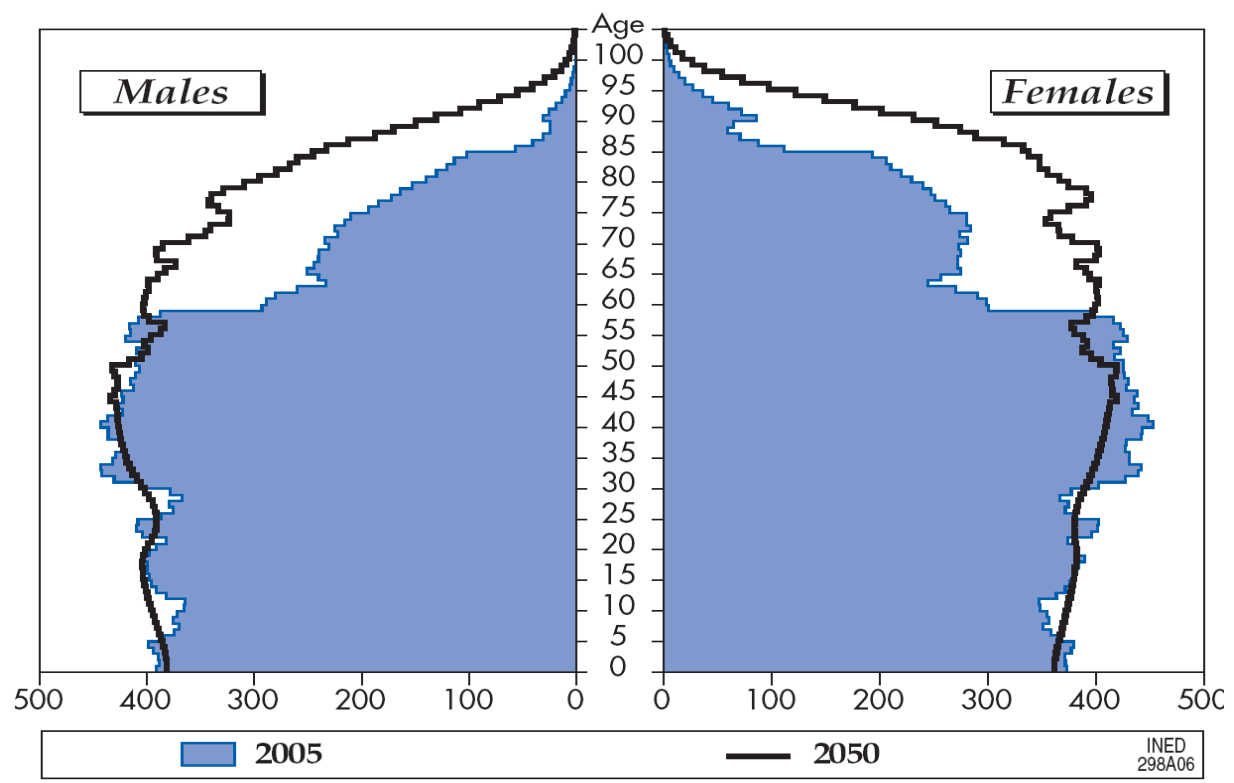

Sources: INSEE, Population projection, medium scenario. Toulemon, Robert-Bobée, 2006

\subsection{Ageing of fertility}

The current level of fertility is constant, but the timing of fertility is changing rapidly in France. The general schedule of age-specific fertility rates is moving to higher ages (Figure 3). During the first half of the 20th century, fertility was almost stable at all ages below 25, and declining at ages over 25. After the Second World War, the baby boom was the result of a dramatic increase in fertility at all ages before 35 , while fertility continued to decrease at higher ages, due to the decline in large families. The baby boom ended between 1966 and 1974, and fertility declined at all ages. Since 1974, 
the total fertility rate has been stable while the fertility schedule has moved to higher ages, with the shape of the fertility schedule becoming more and more symmetrical around the mean age at childbirth. Several trends emerged during the $20^{\text {th }}$ century, and the current shift towards older ages is thus one among many other possible trends (Ní Bhrolcháin and Toulemon 2005).

Figure 3: $\quad$ Age-specific fertility rates in France, selected years

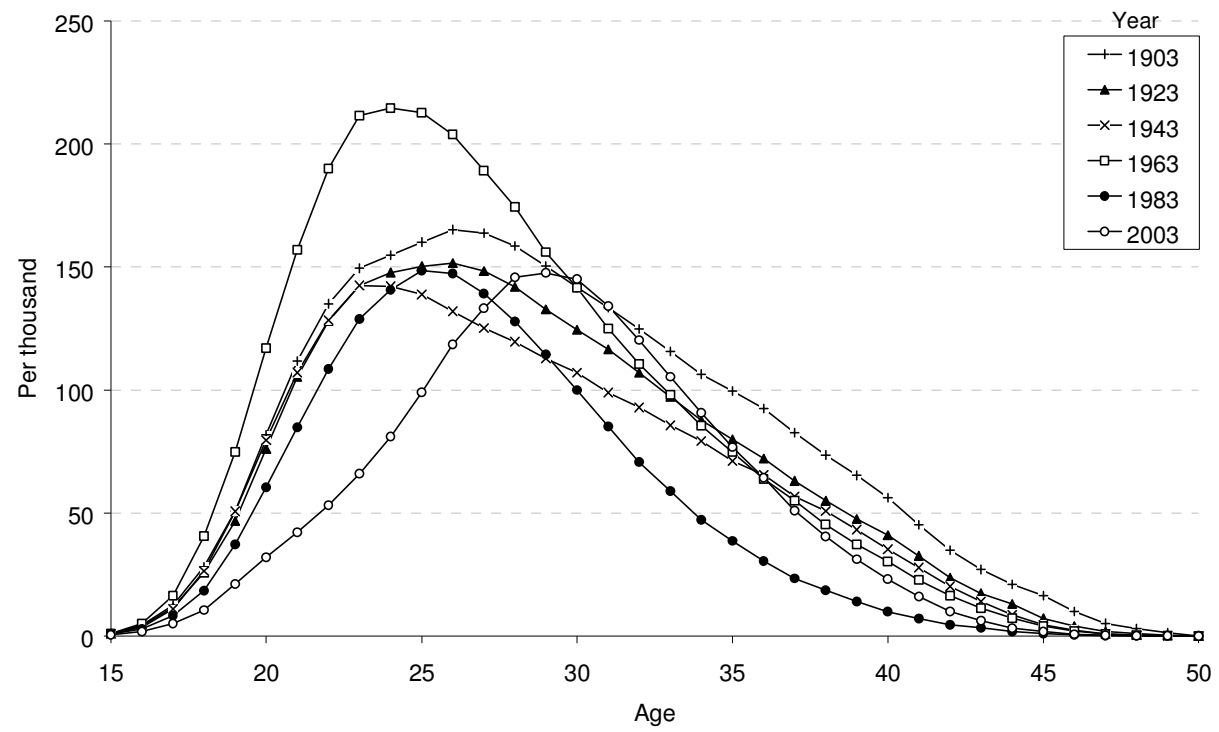

Sources: INSEE, civil registration data. Daguet, 2002; INSEE, 2007.

These trends may also be described age by age. The sum of age-specific fertility rates for 5-year age groups (partial TFR, their sum is equal to the TFR) is plotted in Figure 4 . The stability of the TFR over the last 30 years is the result of diverging trends: a decline in fertility at ages 27 and lower, and an increase at ages 28 and over (Figure 4). For the last 30 years, the relative increase is almost the same at all ages above 33 . Since the second half of the 1990s, fertility at young ages has ceased to decline, while fertility has been continuing to rise at higher ages, which has led to a slight increase in period total fertility, from 1.66 in 1994 to 1.92 in 2005. 
Figure 4: $\quad$ Partial TFR by age group (per 100 women), from 1900 to 2006

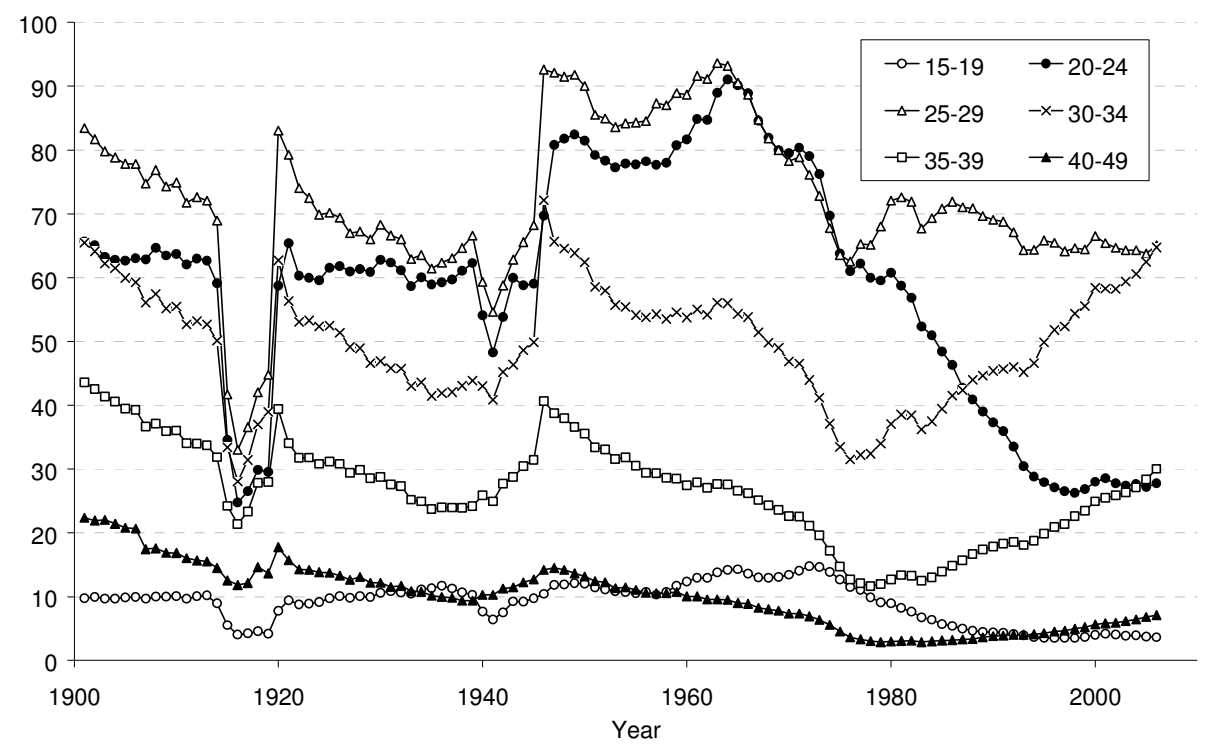

Sources: INSEE, civil registration data. Daguet, 2002; INSEE, 2007; Toulemon, Mazuy, 2001

As a consequence of these changes, the standardized mean age at childbirth is currently increasing (Figure 5). Before 1977, it declined because of both a decline in mean age at first birth and a decrease in high-order births (occurring at higher ages); since 1977, the age at childbirth has increased for all parities (Toulemon and Mazuy 2001), without any change in the distribution of births by order: First births represent $41 \%$ of all births for the whole period 1980-2000. 
Figure 5: $\quad$ Mean age at childbirth from 1900 to 2006 in France, all births and first births

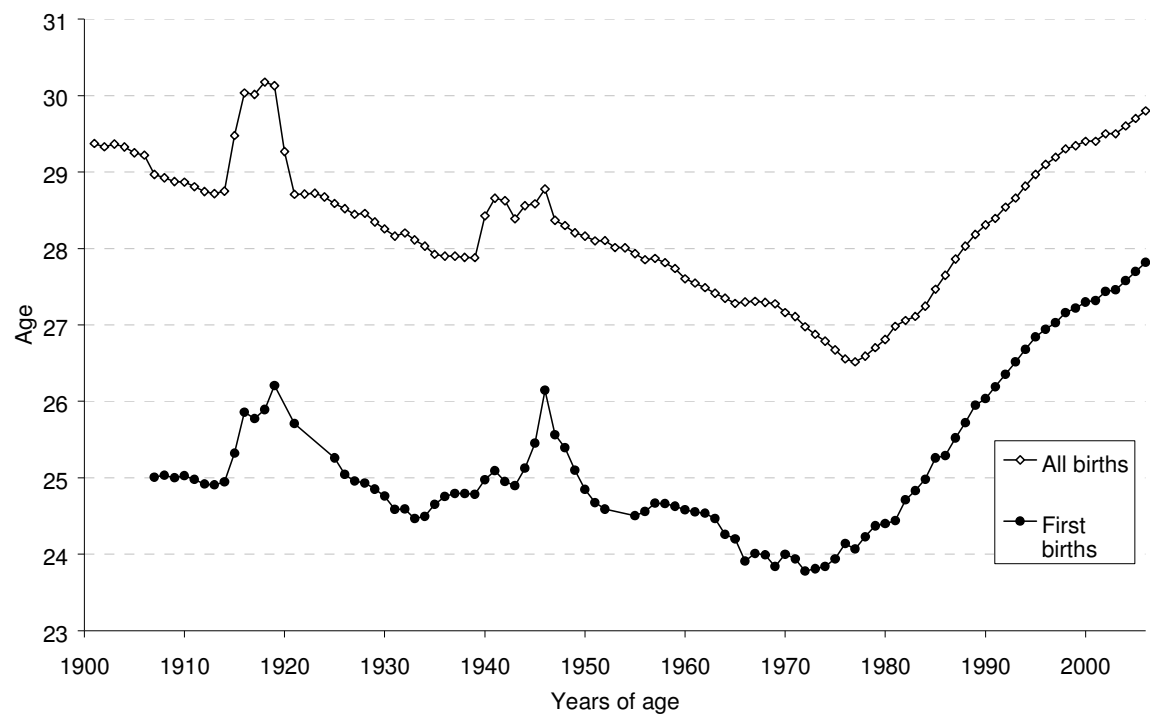

Sources: INSEE, civil registration data. Daguet, 2002; INSEE, 2007; Toulemon, Mazuy, 2001. Authors' projection for age at first birth after 1998

Women born in the 1940s had their first child earliest: During the 1960s, age at first sexual intercourse decreased, while no efficient contraceptive method was available. For subsequent cohorts, the mean age at childbirth rose, mainly due to an increasing age at first birth, while mean birth intervals did not change, according to the 1999 one percent survey on family histories (Toulemon 2001; see also 2.5 below). In the very recent period, no accurate estimate of the mean age at first birth is available, due to the lack of accurate data on birth order from civil registration (Prioux 2005).

\subsection{Cohort fertility assumed to remain stable in future}

Women born in 1950 had 2.12 children on average. Figure 6a shows the cumulative fertility for women born in cohorts 1945 to 1980, by age (more precisely, at the end of the year when each age is reached), and Figure $6 \mathrm{~b}$ shows the cumulative fertility 
relative to cohort 1950, for women belonging to subsequent cohorts, at all ages. Cohorts were followed up to the end of 2004, and additional dots at ages 35, 40, and 45 present the results of the projection shown in Figure 1 for cohorts 1960, 1965 and 1970.

\section{Figure 6a: Cumulative fertility by age}

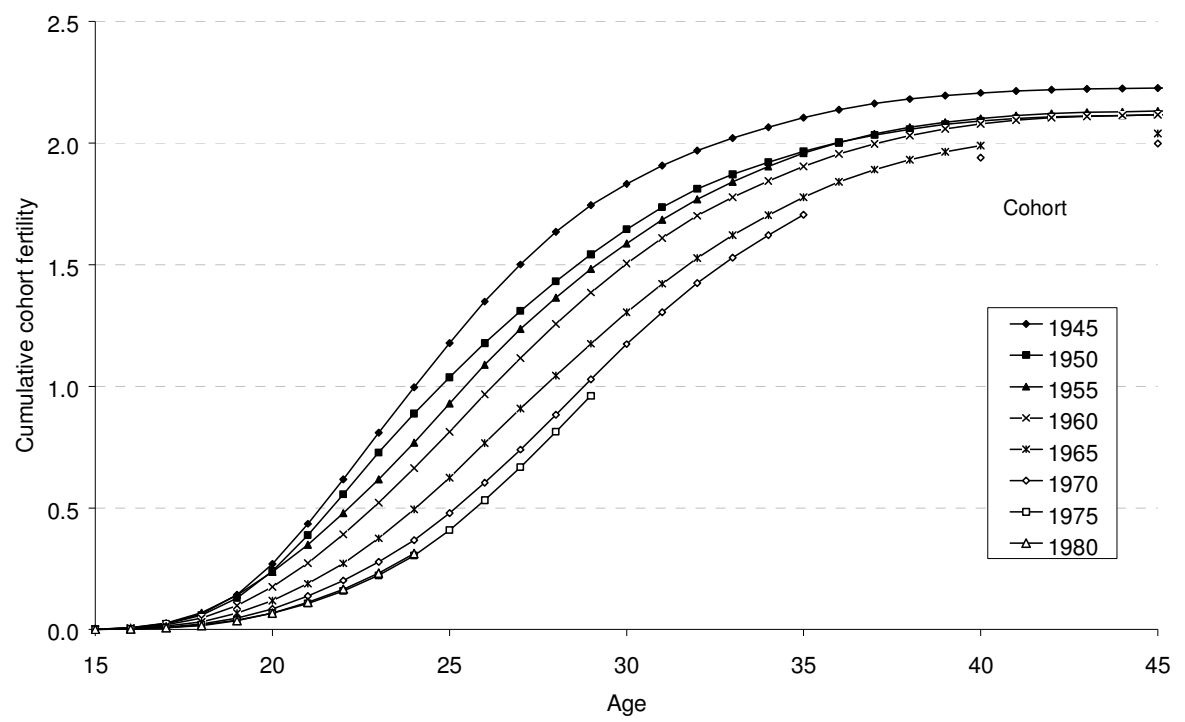

Compared with the 1950 cohort, women born in the 1950s had lower fertility at young ages, showing a cumulative fertility at age 24 of 0.1 fewer children per woman (cohort 1955) or 0.2 fewer (cohort 1960). This gap was filled at the age of 35 (cohort 1955) or 40 (cohort 1960) and total cohort fertility remained stable. For cohorts born after 1960, the gap is much larger: For instance, in the 1970 cohort the cumulative fertility at age 26 is about 0.6 children per woman fewer than for the 1950 cohort. Nevertheless, it is likely that total cohort fertility will remain almost constant; perhaps 0.1 children per woman fewer than for the 1950 cohort (a total of 2.0 children per woman, instead of 2.1), as shown in Figure 1 and by the dots at age 45 in Figure 6. Women born after 1970 do not exhibit any further increasing gap at young ages. Their total fertility might exceed 2.0 children per woman, if the trend of increasing fertility at ages over 28 continues (Toulemon and Mazuy 2001). The stability in fertility rates at ages 20-24 since 1996 (Figure 4) implies that the cumulated fertility at ages 25 is no 
longer decreasing for cohorts born after 1975. As fertility is still increasing at higher ages (see Figure 4), the total fertility rate is increasing too, and cohort fertility could stabilize for cohorts born after 1970 (see Figure 1).

Figure 6b: Cumulative fertility by age compared with women born in 1950 (reference cohort)

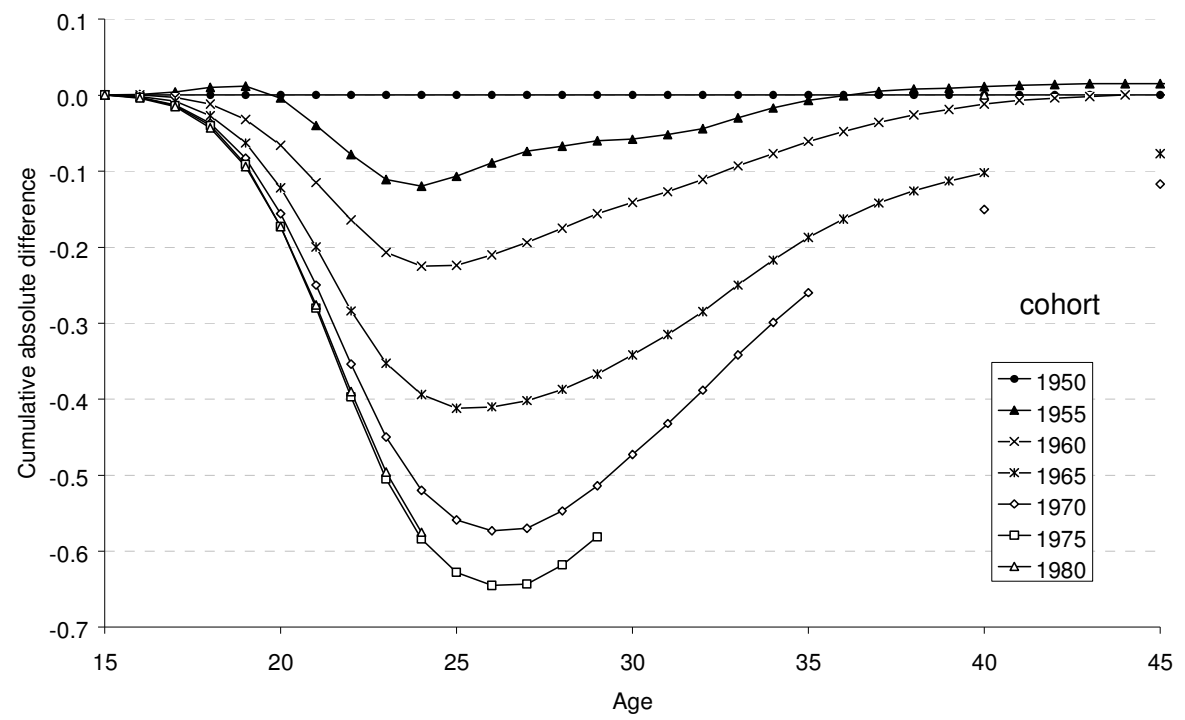

Sources: INSEE, 2007; Prioux, 2005

\subsection{Fertility by parity}

In France, civil registration data by birth order are not accurate, for two reasons. First, young parents are often asked about the number of children born to the same couple or the same marriage and not about the actual birth order of the child among the children from the same mother. Second, census forms do not include any question about parity (the number of children ever born). A specific one per cent survey is thus conducted within each census and among the data gathered is precise information about fertility history (Cassan, Héran, and Toulemon 2000). The latest round of this large-scale survey, called the Family History survey (FHS 1999), took place during the 1999 General Population Census, making it possible to describe accurately fertility trends since the 1960s. Since the end of the baby boom, parity progression ratios have been 
almost stable (Figure 7). The progression to the first child seems to decline, but the changing age at first birth shown in Figure 5 leads to a likely downward bias. The subsequent parity progression ratios, based on duration-specific fertility rates, are stable: The probability of a progression to a second, a third, and a fourth child has not changed since 1975. A comparison with parity progression ratios among cohorts of mothers shows that the cohort parity progressions ratios for women born after 1950 look like moving averages of the period parity progression ratios during the 1980s and 1990s (Toulemon and Mazuy 2001).

Figure 7: $\quad$ Period parity progression ratios based on age-specific first birth rates and parity- and duration-specific rates for births of higher order (PDTFR)

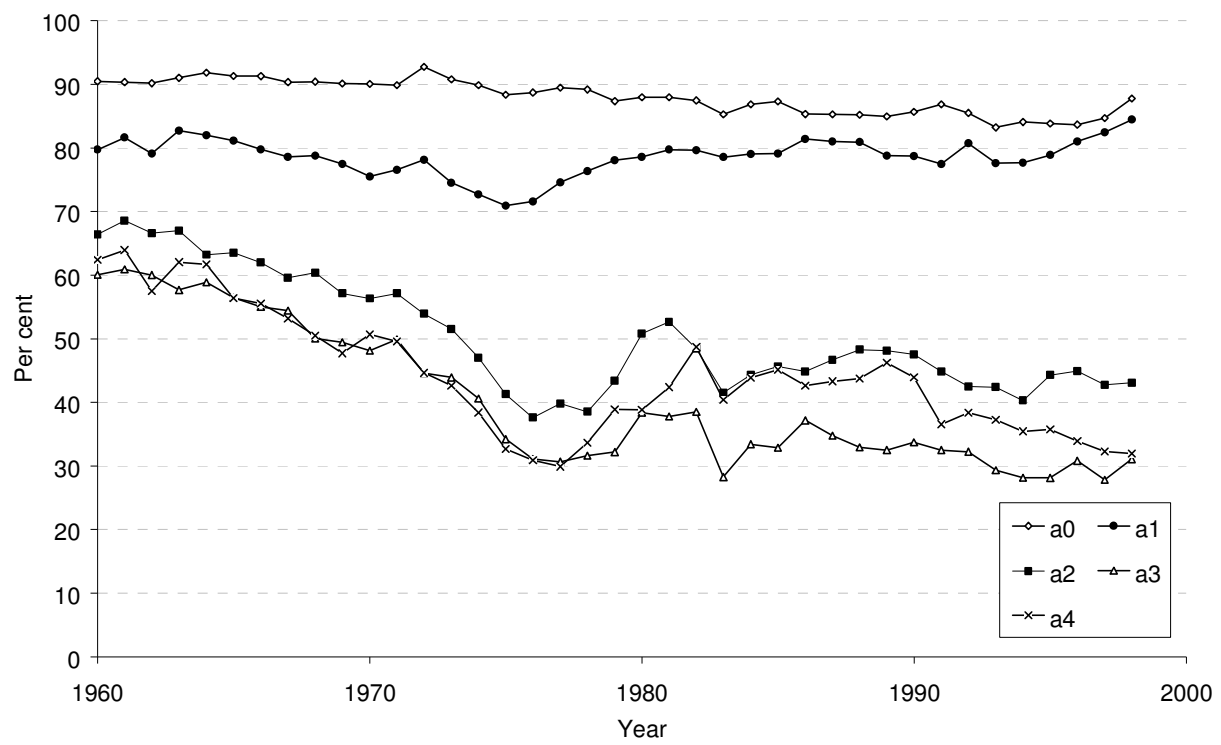

Source: Toulemon, Mazuy, 2001

The cumulated first and second birth rates by age plotted in Figure 8 show that for cohorts born between 1940 and 1950, first and second births were delayed but that by the age of 35 no difference can be found between the cohorts: The proportions of women with at least one or two children are stable. Among women born after 1950, the 
decline in fertility at young ages was not fully compensated at age 35: $84 \%$ of women born in 1960 were already mothers at age 35, compared with $88 \%$ of women born in 1950. The proportion of women who have a first child before age 50 could remain stable at $90 \%$ for cohorts born during the 1950s. It is likely that among younger cohorts more women will have no children at all, but the projected increase in childlessness is very limited: $11 \%$ of women born in 1970 may ultimately remain childless (see Figure 9 below). Cohort childlessness has increased in most Western European countries, except in Northern European states (Sweden, Denmark, Norway), and it is very likely to increase in countries of Central and Eastern Europe (Frejka and Sardon 2006). The evidence for increasing childlessness in France is still very limited, and it is possible that France will experience a very limited increase in childlessness, along with countries from Northern Europe.

Figure 8: $\quad$ Transition to first and second birth by age among women born in 1940-1975

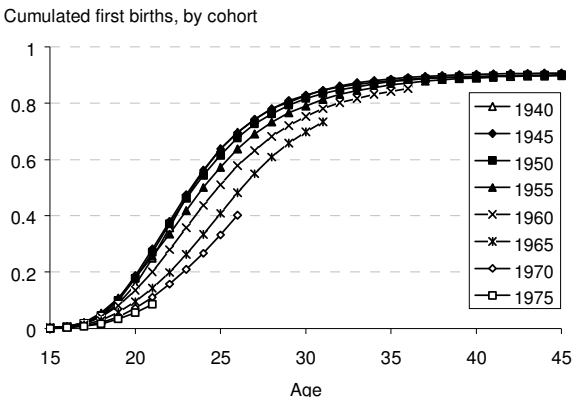

Cumulative absolute change in first births (benchmark cohort 1950)

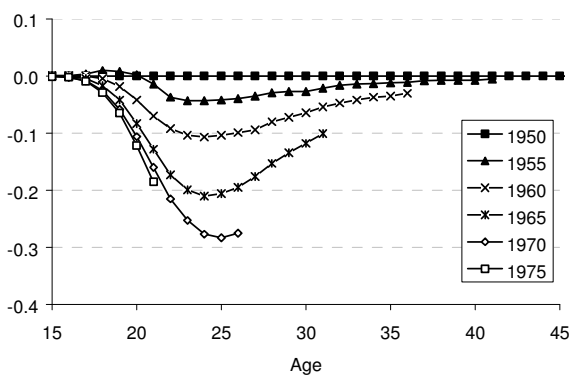

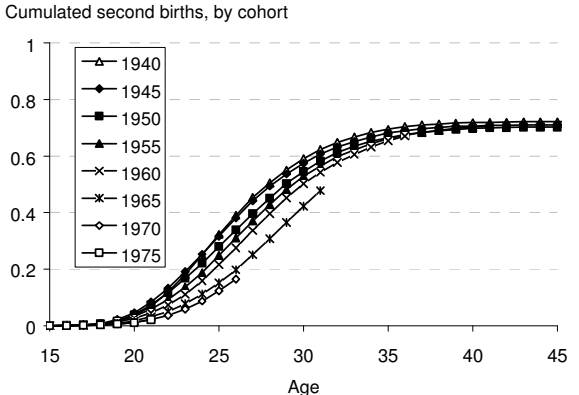

Cumulative absolute change in second births (benchmark cohort 1950)

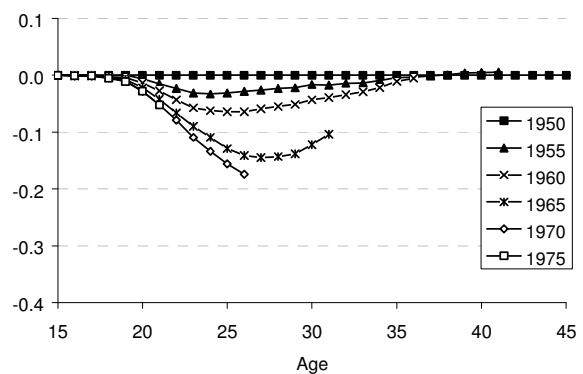

Sources: Toulemon 2001; authors' computations from Insee-Ined, FHS 1999. 
This delay in first births does not lead to a decline in second births. On the contrary, the changes in cumulated second births are smaller, and the proportion of women with two children or more at age 35 moves from $66 \%$ to $65 \%$ for women born in 1940 and 1950 , respectively. The decline is only $1 \%$ at age 35 and it is likely that women born in 1950 will have, at the age of 50, as many second children as women born in 1940. As a consequence, the proportion of women with one child could decrease (Figure 9).

Figure 9: $\quad$ Probability of having a further child within 12 years of a birth, by year of childbirth and birth order

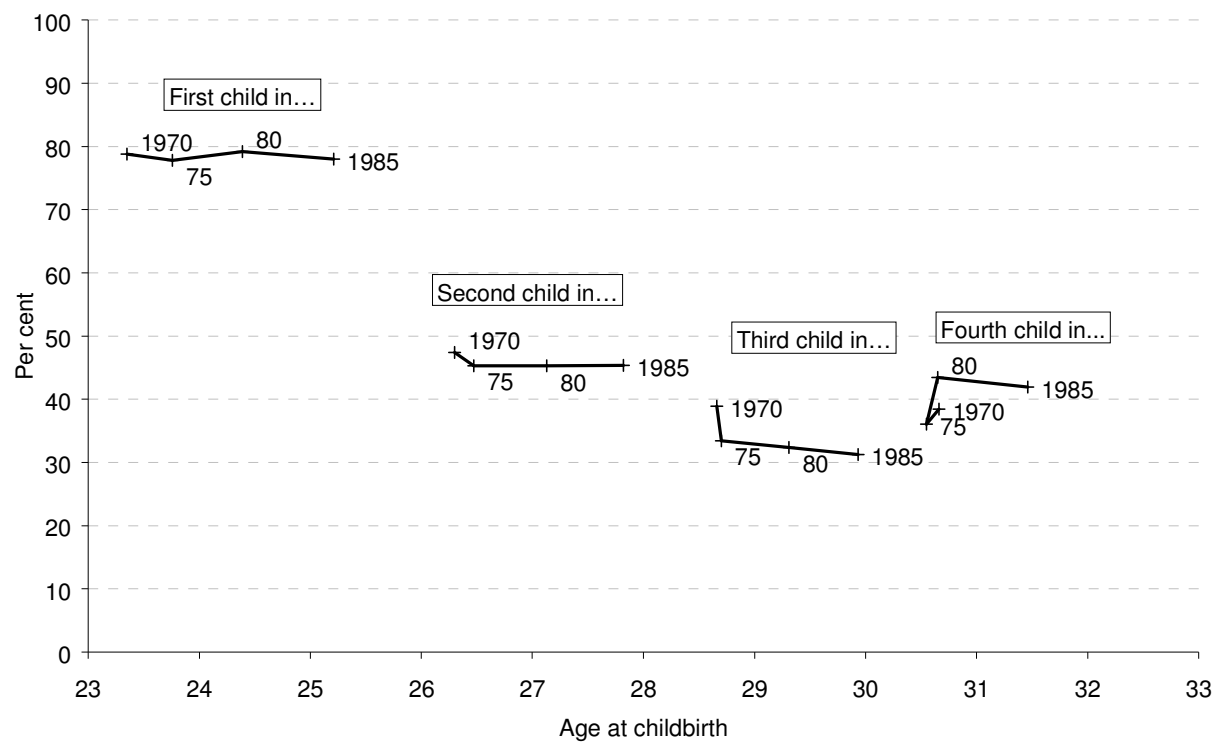

Source: Toulemon, Mazuy, 2001

Among cohorts born after 1970, cumulated first and second birth rates no longer seem to decrease. This can be seen in Figure 6, which presents available data up to 2004: The cumulated fertility at age 24 is constant between cohorts 1975 and 1980 . This is in line with the stability of fertility rates at ages 15-25 since 1995, shown in Figure 4. 
Looking at the progression to the next birth not among periods, but among parity cohorts (children born during the same year) (Figure 9), we see how the increasing mean age at childbirth is linked in France to a stable progression to the next birth, for all birth orders. Since the year 1980, as well as since cohorts of mothers born in 1950, fertility by birth order appears to be very stable, despite an increasing age at childbirth.

In all, cohort fertility is stable around or a little above 2.0 children per woman, while the mean age at birth increases. This stable average fertility is due to a stable distribution of family size. Among women born in 1950, 10\% are childless, $20 \%$ have one child, $40 \%$ two children, $20 \%$ three children, and $10 \%$ have four or more children (Figure 10). A projection of fertility rates shows that the distribution is likely to remain stable, with the childless proportion showing a slight increase from $10 \%$ among women born in 1960 to $12 \%$ for cohort 1980 .

\section{Figure 10: Percentage distribution of women according to the final number of children, by cohort}

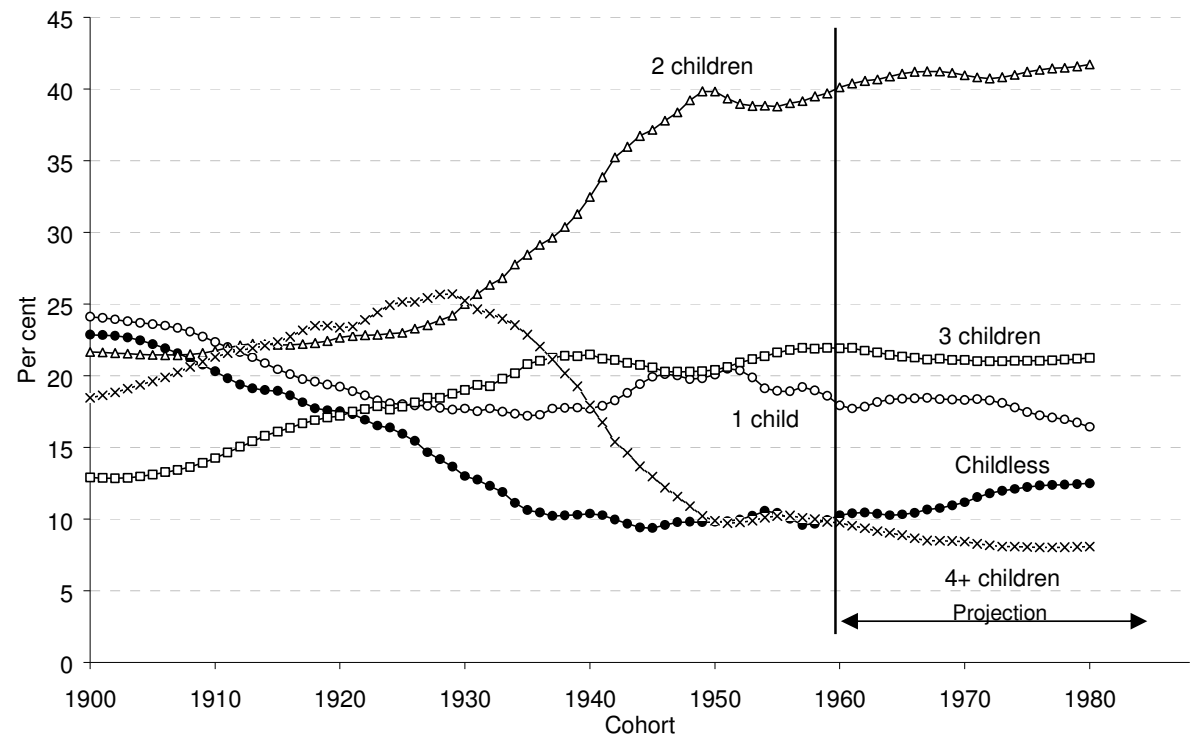

Source: Toulemon, 2001 
This projection is based on parity- and duration-specific fertility rates observed during the 1990s. If the recent increase in fertility is taken into account, the estimate of the proportion of childless women might be even lower. However, women born in 1980 are now aged 25 and their future demographic behaviour is unknown.

\subsection{Educational differentials in fertility are small and decreasing}

Adult education is not common in France; hence, the final educational qualification achieved is a good proxy for social group. Using a methodology pioneered by Britta Hoem (1996), it is possible to construct a variable for level of education that is not correlated with birth cohort, such that it is possible to identify groups of men or women of lower or higher education relative to members of their own birth cohort. To do so, Robert-Bobée and Mazuy (2005) constructed groups with what they termed 'short', 'long' and 'medium' education, as follows: Men and women with two years less than the mean age at the end of enrolment among their cohort were considered to have short education; those with two years more than the mean age were considered to have long education; and those who stopped their education at the median age for their cohort, plus or minus one year, were considered to have a medium education. This enabled them to build groups with around $30 \%$ of the cohort on each side, compared to a medium group 5 .

For men as well as women, the mean number of children has declined among all educational groups (Figure 11). The contrasts are much larger among women than among men. Among women born in 1950-54, who were aged 44-48 at the time of the 1999 FHS survey, the mean number of children ranges from 1.8 among women of long education to 2.4 for women of short education. This constitutes a difference of 0.6 children per woman, as against 0.8 for women born in 1940-44. The contrasts are thus slowly decreasing. Among men, the contrasts almost vanish for recent cohorts.

Among cohorts born in the 1950s, men of short education remain childless a little more often than others, and they also more often have three or more children. The differences are small, but significant due to the large sample size, and the group of less educated men is the most heterogeneous (Figure 12). The contrasts are greater among women: Females of long education are often childless, while their counterparts of short education often have large families. Women of medium education are likely to have exactly two children. Note that, among mothers $(92 \%, 89 \%$, and $83 \%$ of women with short, medium and long education, respectively), the distribution by number of children

\footnotetext{
${ }^{5}$ Among men the distribution is about $40 \%, 35 \%$, and $25 \%$ for short, medium, and long enrolment; among women the corresponding figures are $32 \%, 44 \%$, and $24 \%$.
} 
is almost similar for women of long or medium education, while less educated mothers have more children. In all, the differences are small compared with other European countries. For instance, France does not exhibit such great polarization as Britain, where more women decide to remain childless, especially among the most educated groups (Breton and Prioux 2005; Ekert-Jaffé et al. 2002).

Figure 11: Mean number of children by sex, level of education, and birth cohort

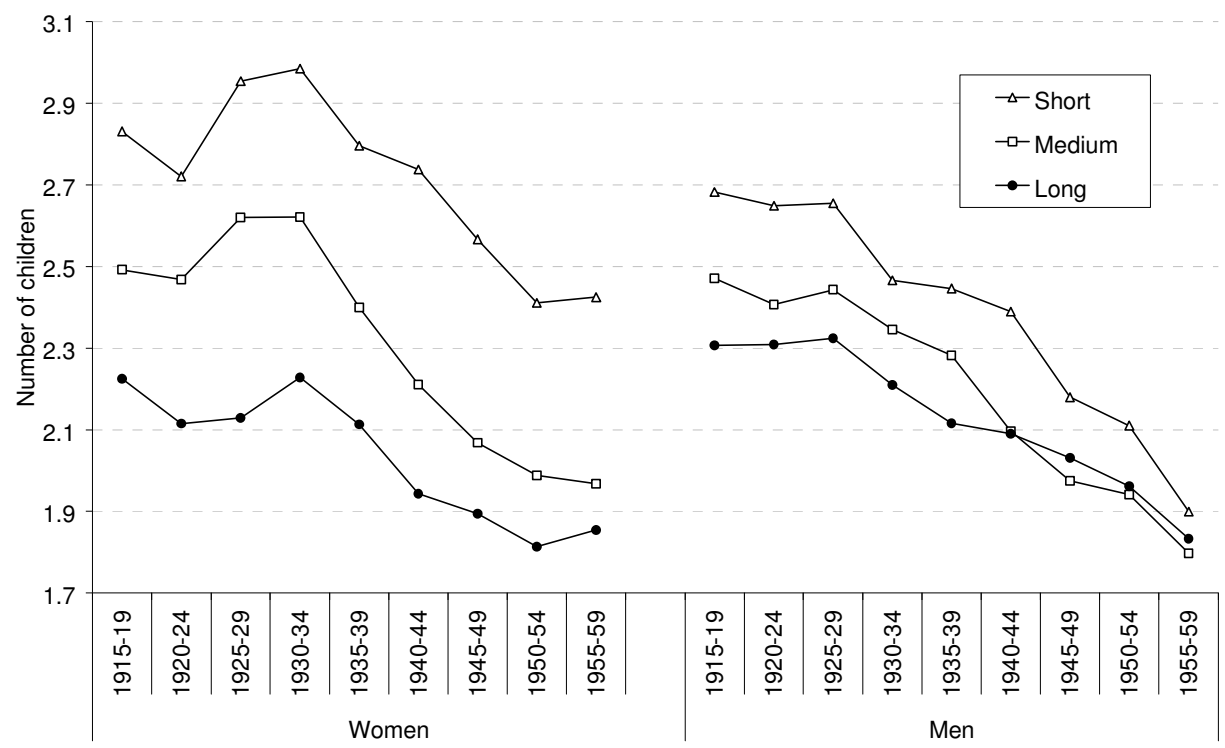

Source: Adapted from Robert-Bobée, Mazuy, 2005. Authors' computations from Insee-Ined, FHS 1999. 
Figure 12: Distribution of men and women born in 1950s by number of children, according to level of education

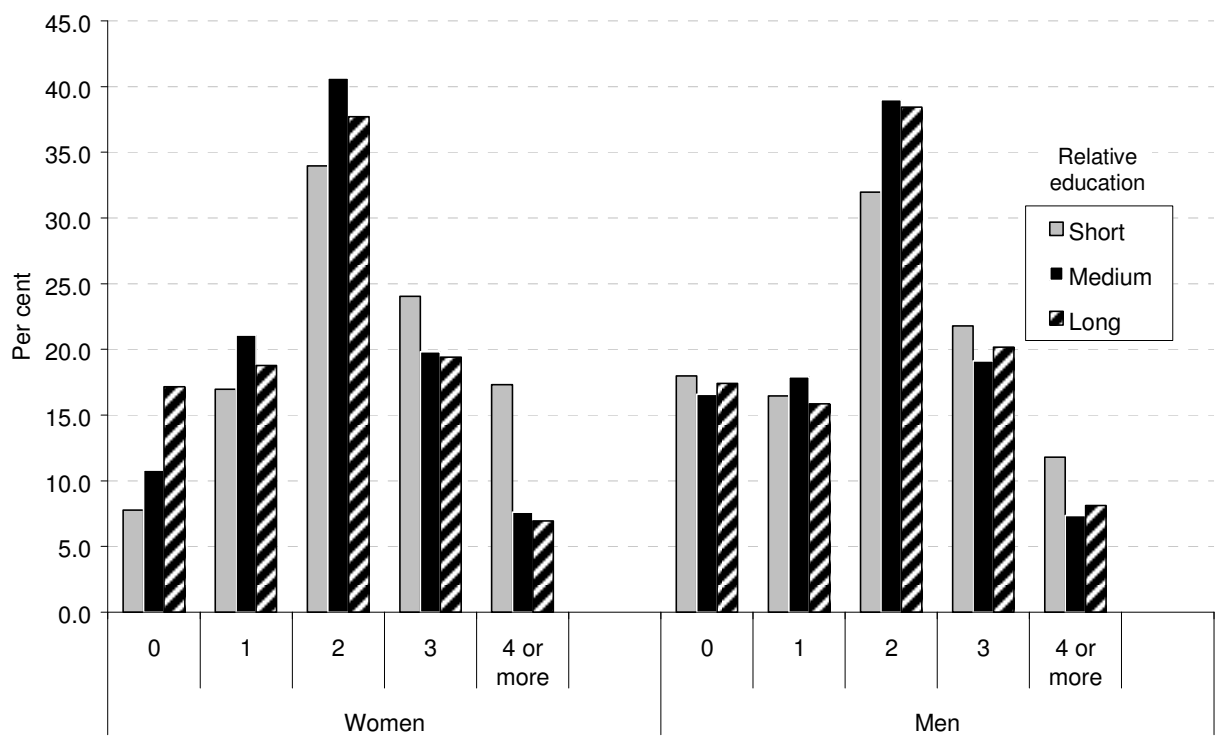

Source: Adapted from Robert-Bobée, Mazuy, 2005. Authors' computations

\subsection{Immigrant and native fertility}

In France, as in most developed countries, immigrant women have higher fertility than women born locally (natives). The total fertility of non-national women, as measured by the usual TFR, is one child more than for women born in France (Legros 2003). However, this estimate, which is based on age-specific fertility rates among nonnationals, is misleading. First, when computed for all immigrant women, including those who have already acquired French nationality, the difference is not 1.0, but 0.85 more children per woman. Second, this index is biased, because it is based on the assumption that fertility depends on age only, which is not true. The bias is large for immigrants, who are observed only after their immigration. Immigrants' fertility before migration to France is low, while their fertility just after migration is very high. There may be several reasons for this discontinuity. Migrants with few children may be selected, if potential migrants who already have children more often give up their migration project. Migrants-to-be might also plan ahead and decide to wait until they 
are already in France before having their intended children. Alternatively, the migrants' behaviour may change upon their arrival in France, due to their experiencing new conditions, such as living as a couple, having access to health services, etc. Given that we do not have any information on immigrants before their migration, it is impossible to disentangle these interpretations, which are not mutually exclusive.

The TFR does not take this discontinuity in migrants' life event histories into account: Age-specific fertility rates are based on exposures in France following migration and do not consider fertility before migration. Furthermore, immigrants arrive in France at various ages, so that for each age group there are newcomers ready to catch up on their fertility, which was delayed before migration. The TFR of immigrants is based on a non-consistent 'synthetic cohort' that would, at all ages, catch up for a nonexistent delay. It thus overestimates the lifetime fertility of immigrants (Toulemon 2006). Taking into account the duration since migration to France to construct a consistent index of lifelong fertility, the estimated excess fertility of immigrants, compared with women born in France, was 0.46 children per women during the 1990s (2.16 vs. 1.70). This is in contrast with the usual TFR, which suggests an apparent difference of 0.85 for lifelong fertility (Table 1). The excess fertility of immigrant women is thus less than 0.5 child per woman. Women from other European countries have a lower total fertility than natives, with the exception of those born in Portugal. Women born on other continents have a higher fertility; the excess is small for women born in Asia ( 0.1 children) and large for women born in Africa (around 1.0 children). For most countries of origin, immigrants' fertility falls behind the fertility in their country of birth and the overall level of fertility in France, except for women born in Portugal, in Tunisia and in Turkey, whose fertility is higher. All in all, if we compute the fertility in the countries of origin of all female immigrants, each country being weighted by the number of immigrant women in France, the level of fertility in countries of birth' is much higher than for immigrant women living in France (2.82 vs. 2.26). This average difference in fertility of $0.66(2.82-2.26)$ is larger than the 0.44 difference between immigrant and native fertility in France (2.26 - 1.70). The fertility of immigrant women in France is closer to the fertility of women born in France than to the overall level of fertility in their countries of origin.

It is often assumed that the high level of fertility in France is due to the immigrant population. However, this assumption is not valid: The overall level of fertility in France in the 1990s would be a mere 0.07 child per woman less if it were based only on women born in France (Toulemon 2006). Furthermore, immigrants' daughters born in France have exactly the same total fertility as women born in France to mothers themselves born in France (Toulemon 2003). 
Even if net migration increased in the years 2000-2005, the current level of the TFR (1.92) would surely be higher than 1.8 if it were computed only for women born in France.

Table 1: Fertility differentials between immigrant women and women born in France

\begin{tabular}{|c|c|c|c|c|c|c|}
\hline \multirow[t]{2}{*}{ Birthplace } & \multirow{2}{*}{$\begin{array}{l}\text { Average } \\
\text { number of } \\
\text { children } \\
\text { per woman } \\
(1) \\
\end{array}$} & \multirow[b]{2}{*}{$\begin{array}{c}\text { total } \\
\text { differential }\end{array}$} & \multicolumn{2}{|c|}{$\begin{array}{l}\text { Fertility differential with } \\
\text { women born in France } \\
\text { of which: }\end{array}$} & \multirow{2}{*}{$\begin{array}{l}\text { Fertility of } \\
\text { women in } \\
\text { the country } \\
\text { of origin } \\
\text { (2) }\end{array}$} & \multirow{2}{*}{$\begin{array}{c}\text { Distribution } \\
\text { of women } \\
\text { aged } 18-49 \\
\text { in } 1999 \\
\text { (per cent) }\end{array}$} \\
\hline & & & $\begin{array}{c}\text { pre- } \\
\text { migration }\end{array}$ & $\begin{array}{c}\text { post- } \\
\text { migration }\end{array}$ & & \\
\hline All females & 1.74 & & & & & 100 \\
\hline Women born in France & 1.70 & - & - & - & & 86.3 \\
\hline Immigrant women & 2.16 & 0.46 & -0.09 & 0.55 & 2.82 & 9.4 \\
\hline Other* & 1.86 & 0.16 & 0.01 & 0.15 & & 4.3 \\
\hline \multicolumn{7}{|l|}{ Country of birth of immigrants } \\
\hline Spain & 1.52 & -0.18 & -0.26 & 0.08 & 1.23 & 0.4 \\
\hline Italy & 1.60 & -0.11 & -0.34 & 0.23 & 1.24 & 0.4 \\
\hline Portugal & 1.96 & 0.25 & 0.12 & 0.14 & 1.49 & 1.3 \\
\hline Other European Union country & 1.66 & -0.05 & -0.32 & 0.27 & 1.44 & 0.7 \\
\hline Other European country & 1.68 & -0.03 & -0.20 & 0.18 & 1.41 & 0.5 \\
\hline Algeria & 2.57 & 0.87 & 0.08 & 0.79 & 3.64 & 1.2 \\
\hline Morocco & 2.97 & 1.26 & 0.23 & 1.03 & 3.28 & 1.3 \\
\hline Tunisia & 2.90 & 1.20 & 0.12 & 1.07 & 2.73 & 0.4 \\
\hline Other African country & 2.86 & 1.16 & 0.06 & 1.10 & 5.89 & 1.1 \\
\hline Turkey & 3.21 & 1.51 & 0.23 & 1.28 & 2.90 & 0.5 \\
\hline Other Asian country & 1.77 & 0.07 & -0.18 & 0.25 & 2.85 & 0.9 \\
\hline America or Oceania & 2.00 & 0.29 & -0.31 & 0.61 & 2.54 & 0.4 \\
\hline
\end{tabular}

France: excluding overseas departements (DOM)

* : born French abroad or born in the DOM

(1) : total period fertility rate allowing for age at entry into France

Scope: women and births, 1991-8

(2) : Standard period total period fertility rates, 1990-9 ; source United Nations, 2003

Source : Insee-Ined, Study of Family History survey, 1999. 


\section{Changes in family behaviour since the 1970s}

In the late 1960s, young people, and especially young women, in France as elsewhere in Europe, wanted more autonomy and greater gender equality. This period marks the beginning of substantial changes in gender and generational power relations. Educational practices changed over the next few decades. An emphasis on relatively strict discipline with children was replaced by a more rational, reasoning approach. The child became an equal member of the family. Nowadays, more time and attention is devoted to children and parenting is increasingly valued (de Singly 1996, 2000). Gender relations have changed as well; women have entered the labour market, and men have taken on some educational tasks (Ferrand 2004). Anthropologists and sociologists report that norms regulating sexual behaviour tend to reflect existing social hierarchies (Godelier 2004). It is thus understandable that these changes in power relations were accompanied by a change in sexual behaviour, thanks also to the 'contraceptive revolution' which made effective, new medical methods available to women (Leridon $e t$ al. 1987). Sexuality was separated from reproduction in the late 1960s. This change led to, and in turn was greatly facilitated by, the introduction of medical contraception and the legalization of abortion. Contraception was legalized in France in 1967 and abortion in 1975.

The functions of the family have changed over the last few decades. It has become less of a place to reproduce generational and gender hierarchies, and more of a special space where individuals forge their identity (de Singly 1996; 2000; Kaufmann 2004). Feelings and love have become the centre of the family, a trend that explains the weakening of the conjugal bond, the loss of popularity of marriage, and the growing complexity of marital trajectories. Contemporary French family sociologists do not view these changes as signifying the 'end of the family'. On the contrary, the family seems to have adapted rather well to the increased weight put on individual autonomy (Attias-Donfut 2002; Segalen 2000). Although the conjugal bond has grown weaker, the parent-child relation has become stronger, a trend that may be seen, for example, in the greater acceptance of social parenthood, including homosexual parenting (Godelier 2004).

\subsection{Decline of marriage}

After peaking in the early 1970s, the annual number of marriages fell regularly to a low plateau in the late 1980 s of fewer than 300,000 per year, among which only 220,000 were women's first marriages. As 'marriageable cohorts' contain around 400,000 women, this implies a total first marriage rate of around 0.5 . The total marriage rate, 
computed from first marriage probabilities (life table estimates), was as low as 0.64 first marriages per woman in 2005. The intensity of first marriage increased in 1996, due to a change in the income tax rules. However, since 2000, the downward trend that began in the mid-1970s has again been evident (Prioux 2005; Beaumel et al. 2006). It shows that marriage is no longer a norm that applies to everyone. Since the mid-1980s, only one first union out of 10 has begun with a formal marriage, while nine out of 10 have begun with a period of unmarried cohabitation. It remains an open issue whether female first marriages will become more common after the age of 50, given that more and more unmarried women are living as a couple and inheritance taxes are very unfavourable to unmarried couples (Toulemon 1997). However, no such trend is apparent at present (Beaumel et al. 2006). First unions are taking place later than before and the proportion of men and women who will not live in a union before the age of 50 may increase slightly, from 6\% among women born in 1950 to $7 \%$ for women born in 1970 (Prioux 2003). This decline in the proportion of women living in union is very limited compared to the decline of marriage. The number of births outside of marriage began to increase at the end of the 1970s and by 2010 they will probably outnumber births within marriage (Figure 13).

Note that, as in Southern European countries, the legal recognition of children is not compulsory. Almost $100 \%$ of children are recognized officially by their mother and some $94 \%$ are recognized by their father, a proportion that has been stable since the 1960s. The others may be recognized at a later age (Muñoz-Pérez and Prioux 2000). Parents who recognize a child born out of marriage have exactly the same rights and duties as married parents. All differences between the rights of children born inside or outside of marriage have been removed from the law. These rules were not established to increase fertility, but to guarantee equality among children. Nevertheless, the decline in marriage did not have any impact on fertility, because births may easily occur out of marriage. 
Figure 13: Annual number of marriages and births, France, 1960-2006

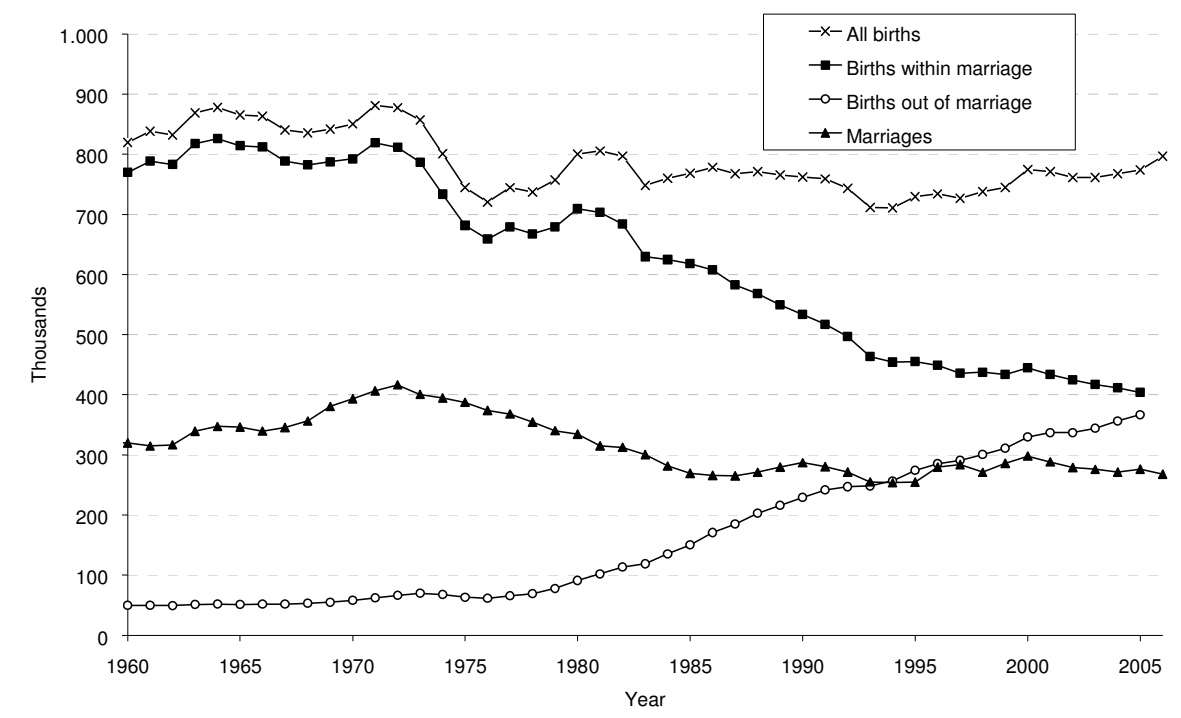

Sources: INSEE, 2007, civil registration data.

It is too early to estimate the impact on family behaviour of the new form of union called Pacte civil de solidarite (Pacs), which is available for homosexual couples but also chosen by many heterosexual couples. This is all the more so, given that it is not, up to 2007, possible to obtain accurate figures on unions and disruptions by sex of partners (Festy 2001).

As a consequence of the decline of marriage, the proportion of married couples is falling steadily (Table 2). Between 1990 and 2004, the proportion of unmarried couples rose from $11 \%$ to $19 \%$. The increase was more pronounced for unmarried couples with one child or, even more, two children and over, while the number of married couples living with children continued to decrease.

The changes in de facto conjugal situations are much less pronounced than for de jure situations, because most people still live as a couple without much change in the propensity to enter a union (Prioux 2003). Nevertheless, new family forms, such as single parents and stepfamilies, are increasing (Lefèvre and Filhon 2005). These family forms imply stronger gender differences than the previous norm of a nuclear family with two parents and children. Single parents are most often single mothers: $2 \%$ of men 
Table 2: $\quad$ Distribution of 100 couples by legal status and number of children living with a couple. France, 1990-2004

\begin{tabular}{|c|c|c|c|c|c|c|c|c|c|}
\hline & 1990 & 1992 & 1994 & 1996 & 1998 & 2000 & 2002 & 2004 & \\
\hline All couples & 100 & 100 & 100 & 100 & 100 & 100 & 100 & 100 & $2004 / 1990$ \\
\hline Unmarried & 10.7 & 13.0 & 14.1 & 15.0 & 16.4 & 17.2 & 18.2 & 19.6 & 2.05 \\
\hline Married & 89.3 & 87.0 & 85.9 & 85.0 & 83.6 & 82.8 & 81.8 & 80.4 & 0.49 \\
\hline With no child & 55.0 & 56.0 & 56.8 & 57.3 & 57.8 & 58.6 & 58.6 & 59.3 & 1.19 \\
\hline With one child & 19.5 & 19.2 & 18.6 & 18.6 & 18.3 & 17.9 & 18.2 & 17.5 & 0.88 \\
\hline With children & 25.5 & 24.8 & 24.6 & 24.1 & 23.9 & 23.6 & 23.1 & 23.3 & 0.88 \\
\hline Unmarried, no child & 6.8 & 7.8 & 8.4 & 8.7 & 9.1 & 9.2 & 9.6 & 10.2 & 1.54 \\
\hline Unmarried, one child & 2.3 & 3.1 & 3.4 & 3.6 & 4.0 & 4.4 & 4.7 & 4.9 & 2.17 \\
\hline Unmarried, 2 children or more & 1.5 & 2.1 & 2.3 & 2.8 & 3.3 & 3.6 & 4.0 & 4.5 & 3.14 \\
\hline Married, no child & 48.1 & 48.2 & 48.4 & 48.6 & 48.7 & 49.4 & 49.1 & 49.1 & 1.04 \\
\hline Married, one child & 17.1 & 16.1 & 15.1 & 15.0 & 14.3 & 13.5 & 13.6 & 12.5 & 0.69 \\
\hline Married, 2 children or more & 24.1 & 22.7 & 22.3 & 21.4 & 20.6 & 19.9 & 19.2 & 18.8 & 0.73 \\
\hline
\end{tabular}

Sources: Authors' computations from INSEE, employment surveys

Note: The odds ratios OR in the last column compare, for each indicator, the proportion $p_{1}$ in 1990 and $p_{2}$ in 2004. They are computed as $\left[p_{2} /\left(1-p_{2}\right)\right] /\left[p_{1} /\left(1-p_{1}\right)\right]$. They allow to compare proportions spread along the whole spectrum $] 0 ; 1[$. The OR is near to 0.5 for married couples and to 2 for unmarried couples, whose proportion almost doubled. The increase appears to be more pronounced for unmarried couples with children.

and $9 \%$ of women aged 18-49 are living with children and without a partner (Table 3), and stepfamilies more often comprise a mother and a stepfather rather than a father and a stepmother (Toulemon and Knudsen 2006).

The declining trend in marriages and the increase in unmarried cohabitation, divorces, and de facto separation (Lefèvre and Filhon 2005; Prioux 2005; Sardon 2004) are similar to that which is occurring in many other European countries. Hence, the conclusion that France is an outlier in all demographic behaviours is unwarranted.

\subsection{Contraceptive use and abortion}

Medical contraception was legalized in 1967 in France and the costs of purchasing it have been reimbursed by social security since 1974. Four cross-sectional surveys in 1978, 1988, 1994 and 2000 shed light on the increasing use of medical methods of contraception. The number of women at risk of an unwanted pregnancy while not using contraception was already very low in 1978 (3.7\% in 1978, 1.8\% in 2000). The main 
change observed is the shift from non-medical to reversible medical methods. The pill and the IUD were used by $36.9 \%$ of women aged 20 to 44 in 1978, and $62.7 \%$ in 2000, the IUD mainly by women with children. Sterilization for the purpose of contraception was formally legalized only in 2001, but $4.7 \%$ of women aged 20 to 44 were sterilized in 2000 (Leridon et al. 2002; Bajos et al. 2004). The reconstitution of cohort series from the retrospective contraceptive data collected in the 1988 survey shows that among women born in 1938-1942, 49\% have used the pill or an IUD before age 50, while 95\% of women born in 1963-1967 will have done so (Toulemon and Leridon 1991). The replacement of 'natural' methods (withdrawal and periodic abstinence) by medical methods of contraception was achieved at the end of the 1980s. The proportion of users of medical methods continued to increase slightly in the 1990s at young ages, due to the delay in fertility. Following the emergence of the AIDS epidemic, the condom became the most popular means of contraceptive sexual initiation: While $23 \%$ of women who had their first intercourse between 1968 and 1974 used a condom, 59\% did in 1995-2000 (in combination with the pill or alone) (Rossier, Leridon et al. 2004). This trend did not result in a fall in the proportion of young women who used medical contraception after they had been in a relationship for a time.

Table 3: $\quad$ Total population and distribution of 100 men and women aged 18 to 49 by conjugal status and presence of children and stepchildren

\begin{tabular}{|c|c|c|c|c|c|c|c|c|}
\hline \multirow[b]{2}{*}{ Thousands } & \multicolumn{4}{|c|}{ Men } & \multicolumn{4}{|c|}{ Women } \\
\hline & All & $\begin{array}{l}\text { Not in } \\
\text { couple }\end{array}$ & $\begin{array}{c}\text { Married } \\
\text { couple }\end{array}$ & $\begin{array}{l}\text { Unmar. } \\
\text { couple }\end{array}$ & All & $\begin{array}{l}\text { Not in } \\
\text { couple }\end{array}$ & $\begin{array}{r}\text { Married } \\
\text { couple }\end{array}$ & $\begin{array}{l}\text { Unmar. } \\
\text { couple }\end{array}$ \\
\hline All & 10195 & 2595 & 5191 & 2410 & 11067 & 2660 & 5923 & 2485 \\
\hline No child & 4613 & 2392 & 1110 & 1112 & 4299 & 1699 & 1476 & 1125 \\
\hline Children & 5582 & 203 & 4081 & 1298 & 6768 & 961 & 4447 & 1360 \\
\hline \multirow[t]{2}{*}{ Stepchildren } & 441 & 0 & 219 & 222 & 467 & 0 & 224 & 244 \\
\hline & \multicolumn{4}{|c|}{ Men } & \multicolumn{4}{|c|}{ Women } \\
\hline Per cent & All & $\begin{array}{l}\text { Not in } \\
\text { couple }\end{array}$ & $\begin{array}{c}\text { Married } \\
\text { couple }\end{array}$ & $\begin{array}{l}\text { Unmar. } \\
\text { couple }\end{array}$ & All & $\begin{array}{l}\text { Not in } \\
\text { couple }\end{array}$ & $\begin{array}{c}\text { Married } \\
\text { couple }\end{array}$ & $\begin{array}{l}\text { Unmar. } \\
\text { couple }\end{array}$ \\
\hline All & 100 & 25.5 & 50.9 & 23.6 & 100 & 24.0 & 53.5 & 22.5 \\
\hline No child & 45.2 & 23.5 & 10.9 & 10.9 & 38.8 & 15.4 & 13.3 & 10.2 \\
\hline Children & 54.8 & 2.0 & 40.0 & 12.7 & 61.2 & 8.7 & 40.2 & 12.3 \\
\hline Stepchildren & 4.3 & 0.0 & 2.1 & 2.2 & 4.2 & 0.0 & 2.0 & 2.2 \\
\hline
\end{tabular}

Sources: Authors' computations from INSEE, employment survey, 2004. Men and women reference person of the household or his/her partner.

Bold: People living as a single parent. Italics: people living in a stepfamily, as a parent and/or as a stepparent 
Table 4: $\quad$ Main contraceptive methods used in 2000, France, for 100 women in each age group

\begin{tabular}{|c|c|c|c|c|c|c|c|c|}
\hline Age at 1.1.2001 & $18-19$ & $20-24$ & $25-29$ & $30-34$ & $35-39$ & $40-44$ & $\begin{array}{c}\text { All } \\
18-44\end{array}$ & $\begin{array}{c}\text { All } \\
20-44\end{array}$ \\
\hline Year of birth & $\begin{array}{c}1981- \\
1982\end{array}$ & $\begin{array}{l}1976- \\
1980-\end{array}$ & $\begin{array}{c}1971- \\
1975\end{array}$ & $\begin{array}{c}1966- \\
1970\end{array}$ & $\begin{array}{c}1961- \\
1965\end{array}$ & $\begin{array}{c}1956- \\
1960\end{array}$ & $\begin{array}{l}1956- \\
1982\end{array}$ & $\begin{array}{c}1956- \\
1980\end{array}$ \\
\hline \multicolumn{9}{|l|}{ Proportion of women: } \\
\hline $\begin{array}{l}\text { Currently using a reversible method: } \\
\text { of which }\end{array}$ & 63.3 & 79.3 & 76.1 & 72.4 & 74.5 & 70.6 & 73.6 & 74.5 \\
\hline Pill and condom & 15.0 & 6.5 & 1.3 & 1.4 & 0.9 & 0.2 & 2.9 & 2.0 \\
\hline Pill & 38.9 & 61.8 & 55.4 & 42.3 & 32.3 & 27.8 & 42.9 & 43.3 \\
\hline IUD & 0.0 & 0.9 & 7.5 & 18.3 & 27.6 & 29.6 & 16.1 & 17.4 \\
\hline Condom & 9.2 & 8.6 & 7.7 & 8.0 & 6.2 & 6.7 & 7.5 & 7.4 \\
\hline Local feminine methods & 0.2 & 0.0 & 0.1 & 0.4 & 0.5 & 0.9 & 0.4 & 0.4 \\
\hline Periodic abstinence & 0.0 & 0.8 & 0.8 & 0.4 & 2.9 & 1.7 & 1.2 & 1.3 \\
\hline Withdrawal & 0.0 & 0.2 & 3.2 & 1.4 & 3.5 & 2.6 & 2.1 & 2.2 \\
\hline ...Other methods, unspecified & 0.0 & 0.5 & 0.1 & 0.2 & 0.6 & 1.1 & 0.5 & 0.5 \\
\hline $\begin{array}{l}\text { Not using a reversible method: } \\
\text { of which }\end{array}$ & 36.7 & 20.7 & 23.9 & 27.6 & 25.5 & 29.4 & 26.4 & 25.5 \\
\hline Sterilized & 0.0 & 0.0 & 0.3 & 0.9 & 5.7 & 16.3 & 4.5 & 4.8 \\
\hline Sterile & 0.0 & 0.0 & 0.6 & 0.5 & 1.7 & 4.2 & 1.3 & 1.5 \\
\hline Pregnant & 1.5 & 1.8 & 7.1 & 6.9 & 3.3 & 0.4 & 3.8 & 3.9 \\
\hline No sexual relations & 33.3 & 17.1 & 6.6 & 8.4 & 6.5 & 3.5 & 10.0 & 8.2 \\
\hline Seeking to conceive & 0.0 & 1.4 & 7.0 & 6.9 & 4.6 & 1.9 & 4.1 & 4.4 \\
\hline Other situations & 1.9 & 0.4 & 2.3 & 4.0 & 3.7 & 3.1 & 2.7 & 2.7 \\
\hline All & 100.0 & 100.0 & 100.0 & 100.0 & 100.0 & 100.0 & 100.0 & 100.0 \\
\hline $\mathrm{N}$ & 98 & 336 & 578 & 629 & 668 & 554 & 2863 & 2765 \\
\hline
\end{tabular}

Source: INSERM-INED, Cohorte Contraceptive, September 2000 to January 2001, women aged 18-44.

Read as: $15.0 \%$ of women aged 18 to 19 used the pill and the condom at the time of the survey. In the case of multiple responses, the following downward hierarchy was applied: sterilization, then reversible methods in the order displayed in the table. Local feminine methods are: diaphragm, spermicides, sponge, and female condom. 
Abortion rates diminished during the 1980s from 19 abortions per 1000 women of reproductive age in 1981 to 14 per 1000 in 1991 . They have remained stable since 1991 (Rossier and Pirus 2007, Table 5). The fall in the rates of induced abortions during the 1980s corresponds to the rising incidence of the use of medical contraception and hence to the diminution of the rate of unintended pregnancies, whose frequency remained stable during the 1990s (Reignier-Loilier 2005). At younger ages, the propensity to end an unwanted pregnancy has increased since the 1970s, which reflects the greater demand for fertility control due to the delay in fertility. After the rate of unintended pregnancies stopped falling at the end of the 1980s, the abortion rate at younger ages increased slightly during the 1990s (Kafé and Brouard 2000). In summary, young people, like the rest of the population, overwhelmingly use medical contraception to prevent unintended pregnancies (only $2 \%$ of women aged 18 to 19 and at risk of an unintended pregnancy do not use contraception, Table 4) but, when an accidental pregnancy occurs, they are ever more likely to interrupt it. France has today a relatively high rate of induced abortion by European standards, with an abortion rate of 14 per 1000 women a year in 2003 (Vilain 2005), which places France just after Englishspeaking and Nordic countries (Henshaw, Singh, and Haas 1999). Blayo (1995) attributes this relatively high rate to the absence of sterilization in France, Bajos (et al. 2004) to the difficulties met by women in managing their daily contraception and to the rather poor quality of contraceptive services.

Table 5: $\quad$ Frequency of induced abortion in France, 1976-2003

\begin{tabular}{cccccc}
\hline Year & $\begin{array}{c}\text { Number of } \\
\text { abortions } \\
\text { declared in the } \\
\text { bulletin (1) }\end{array}$ & $\begin{array}{c}\text { Number of } \\
\text { abortion } \\
\text { estimated by } \\
\text { INED (2) }\end{array}$ & $\begin{array}{c}\text { Ratio of } \\
\text { abortion } \\
\text { per 100 } \\
\text { births }\end{array}$ & $\begin{array}{c}\text { Abortion rate } \\
\text { per 1000 } \\
\text { women aged } \\
15 \text { to } 49\end{array}$ & $\begin{array}{c}\text { Total } \\
\text { Abortion } \\
\text { Rate (3) }\end{array}$ \\
\hline 1976 & 134173 & 246000 & 34.1 & 20.0 & 0.67 \\
1981 & 180695 & 245000 & 30.4 & 19.0 & 0.64 \\
1986 & 166797 & 221000 & 28.4 & 16.0 & 0.54 \\
1991 & 172152 & 206000 & 27.1 & 14.0 & 0.49 \\
1996 & 162792 & 207000 & 28.2 & 14.2 & 0.50 \\
2002 & 137497 & 207000 & 27.2 & 14.0 & 0.51 \\
2003 & & 203300 & 26.7 & 14.1 & 0.50 \\
\hline
\end{tabular}

1) http://www.ined.fr/statistiques_ivg/.

2) Estimations by Rossier and Pirus, 2007. After 2002, the annual number of abortions comes from hospital statistics (Vilain 2005).

3) Sum of age-specific abortion rates. Abortions per woman. 


\section{Female and youth participation in the labour force}

Cross-nationally, female participation in the labour force has become positively correlated with the level of fertility in Europe (Billari, Kohler 2004; OECD 2005; Fürnkranz-Prskawetz, Engelhardt, and Mamolo 2005). This positive correlation is also observed in France, when different regions are compared (Del Boca et al 2004).

As in other European countries, women's participation in the labour force has shown a long continuous upward tendency since the 1970s (OECD 2005). The level of female professional activity is high: In 2005 the activity rate of women aged 15 to 59 was $76.5 \%$. This level is lower than that of Northern European countries, such as Finland, Sweden or Denmark. It is similar to that of Portugal or Austria. The increase in female participation in the labour force has occurred irrespective of the number of children: From 1985 to 2002 it rose from $72 \%$ to $84 \%$ for mothers with one child, from $66 \%$ to $80 \%$ for women with two children and from $45 \%$ to $63 \%$ for those with three children. Indeed, the majority of women still work after they have had children; their employment is less often disrupted by childbearing than in other continental European countries. Fourteen percent of working mothers aged 20-49 in 2005 had stopped working after a first birth, $26 \%$ after a second birth, $41 \%$ after a third one (Pailhé and Solaz 2006). Working mothers of young children are well-accepted socially, both by individuals and by firms, whereas the 'housewife' model has become discredited socially. Attitudes towards female work have changed dramatically. According to CREDOC opinion surveys, $41 \%$ of French people thought in 1978 that women should not work while their children were young. This figure fell to $17 \%$ in 2004. More than $60 \%$ think that women should have the free choice to work. So, the dominant model is the two-career one. Among couples aged 20-49 where at least one partner has a job, both partners have jobs in $70 \%$ of cases. The man is the sole earner in $25 \%$ of couples, while the woman is the sole earner in $5 \%$ of couples (Eurostat, labour force survey).

\subsection{Impact of 1994 child care allowance reform on fertility and participation in the labour force}

However, this increasing trend in female participation in the labour force was interrupted in the mid-1990s, due to a reform in family policy with respect to childcare allowance. Since 1994, the childcare leave allowance, which previously could be

\footnotetext{
${ }^{6}$ The female employment rate is lower than the activity rate, because the latter includes unemployed women (see below).
} 
claimed by working women who stop working or begin to work part-time after the birth of a child of order three or more, until the child is three, has also been made available to mothers who give birth to or adopt a second child. This reform has had a great impact on the number of recipients: It tripled in three years, to about 500,000 (of whom only $2 \%$ are fathers). It is estimated that this leave has been an incentive to withdraw from the labour force for at least 112,000 women per year (Afsa 1998; Piketty 2005). The parental leave allowance was extended to mothers of a first child in 2004, for a period of six months after the birth. Even if it does not reach the level of Northern countries, the take-up rate is quite high: $10 \%$ after a first birth, $30 \%$ for second births, and $39 \%$ for births of order 3 and over (Mahieu 2005). The take-up rate for part-time parental leave is rather low: $5 \%, 20 \%$, and 10\%, respectively. The 1994 reform led to a large decline in young mothers' participation in the labour force (Figure 14). Participation in the labour force has decreased rapidly for mothers of two children who have at least one child under three (within three years, the activity rate fell from 69\% in 1994 to $54 \%$ in 1997, its level 15 years before). Nevertheless, job breaks are relatively short on average. Half of parity 1 mothers who stop work return to work after 18 months, and half of mothers of parity 2 or 3 do so after two years (Pailhé and Solaz 2006). Among mothers of one child, women who had their baby after 1994 resume work faster than those who had their baby before. That may be analysed as a cohort effect. However, among mothers of two children, this cohort effect seems to have been counterbalanced completely by the effect of the policy: Over the three years after the birth there is no difference whether the child was born after or before 1994.

The women who are more likely to leave the labour force are those who are less educated, have insecure jobs, poor working conditions, or poor work schedules. A combination of factors affects the decision to leave the labour force. Although women's wages, and to a lesser degree those of their partners, do play a role, the worsening of working conditions and employment opportunities has contributed greatly to the success of the 1994 child care allowance reform (Marc 2004). Parental leave is taken under duress for a large share of women. One half of mothers who have taken paid parental leave declare that they would have preferred to keep on working if their work conditions had been different or if childcare had been available (Méda, Simon, and Wierinck 2003).

The concern about the risk of increased difficulties in finding work after this period of three years (Bonnet and Labbé 1999) has not been borne out. In cases in which women who take parental leave are at risk of unemployment when they return to the labour market, this is due more to their low level of education than their having taken parental leave. Nevertheless, ceteris paribus, women who return to work after parental leave find less qualified jobs than women who have not taken such leave (Algava and Bressé 2005). 
Figure 14: Activity rate of women aged 20-49 living in couple with at least one child under 3, 1990-2005

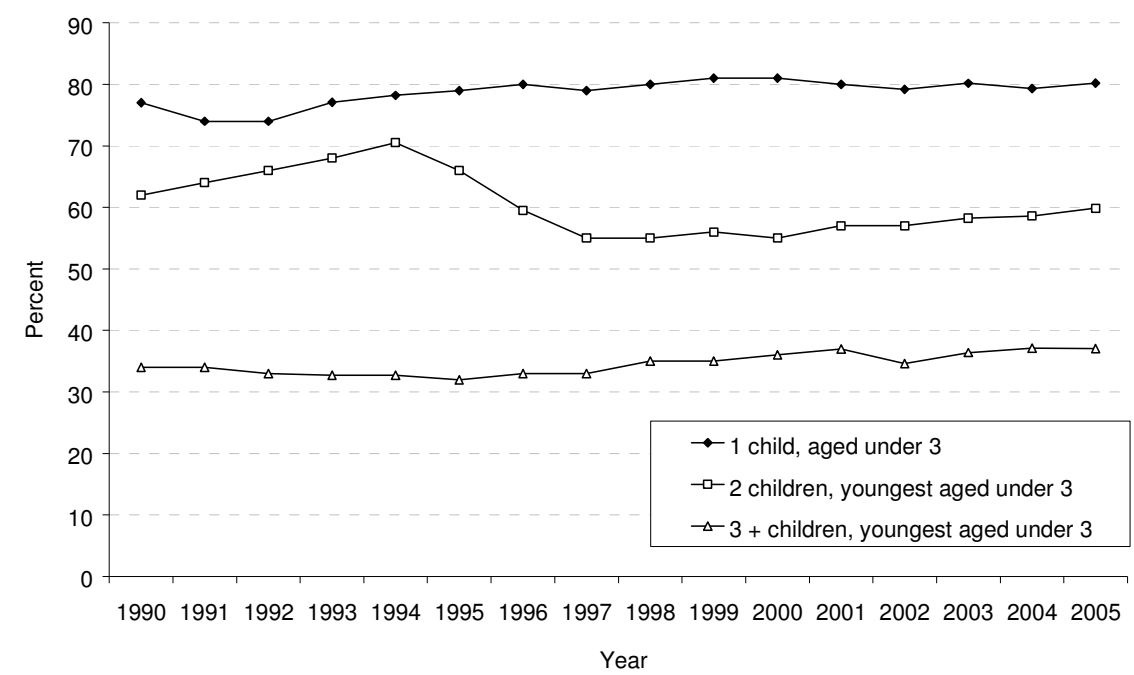

Source: INSEE, Employment surveys

A distinctive feature of female labour force participation in France is that mothers of young children traditionally work full-time, which differs from other countries that have high female participation in the labour force, such as Denmark or Sweden (Aliaga 2005). Twenty-two percent of women aged 20 to 49 work part-time, $18 \%$ of childless women, $21 \%$ of mothers with one child, $32 \%$ of mothers with two children, and $45 \%$ of mothers of three or more children (the EU-25 averages are $27 \%, 20 \%, 33 \%, 44 \%$, and $51 \%$ ). Only $3 \%$ of men aged $20-49$ work part-time. In France, part-time work serves a dual purpose. It both allows women who wish to work less in order to reconcile family and professional work to do so, while it also permits an increase in flexible forms of employment. Unlike in northern countries, the growth of part-time work has appeared mainly in positions without job security, thus becoming a means for companies to circumvent norms of job security. Few women would like to work less: 9\% of women aged 20-49 working full-time would like to work part-time. Large shares of working women (28\%) work in the public sector, compared with $16 \%$ of men $(57 \%$ of the total number of civil servants are women). It is easier for civil servants than for others to work part-time and there are incentives to work part-time: Civil servants working $80 \%$ of full time earn $90 \%$ of the full wage (Aliaga 2005). 


\subsection{Economic situation of young adults}

The average length of studies has increased in France over the course of the last century. However, the median age at the end of schooling stopped increasing for cohorts born after 1975 (Durier 2006). Today, one person in two is still in full-time education after age 20 (Robert-Bobée and Mazuy 2005). Compared with other European countries, young adults are more often students or unemployed in France (Chambaz 2001). Indeed, the unemployment rate of people less than 25 years old is $22 \%$ in France, compared with an average of $18 \%$ in the Euro Zone (Eurostat, http://epp.eurostat.ec.europa.eu/). This could be attributed to the relative difficulty that the rigid French labour market is experiencing in adapting to globalization (Kieffer et al 2005). However, social benefits received by the young are close to the European average: $51 \%$ of people aged 18 to 29 receive some form of social support from the state (Chambaz, 2001). Age at departure from the parental home is also close to the European average: Women born in 1968 left the parental home at a median age of 22.6 and men did so at a median age of 24.5 (Villeneuve-Gokalp 2005). Altogether, 52\% of people 18 to 29 lived with their parents in 1996 (Chambaz 2001). The housing market does not prevent young people from leaving their parents' home. Combining job incomes, state support, and parental support, Chambaz (2001) found that young French people have, on average, one of the highest living standards in the European Union.

\subsection{Age and gender inequalities in unemployment and wages}

As in other European countries, the share of working men and women by profession differs. Women are more present in health- and education-related professions (INSEE 2004). Women are often white-collar at low or medium level, while men are more often blue-collar and high-level white-collar or self employed.

Unemployment is much more frequent among women than among men and also more frequent among young adults (Figure 15). In the short term, the trends in unemployment are linked with entry into first union (Prioux 2005). During the mid1990s, unemployment was high, especially for young adults, and new unions and births declined, while the recovery during the late 1990s was accompanied by an increase of fertility. However, in the early 2000s, unemployment began to increase again, without any noticeable decline in fertility. 
Figure 15: Unemployment rate of men and women aged 15-64, by sex and age group. France, 1990-2004

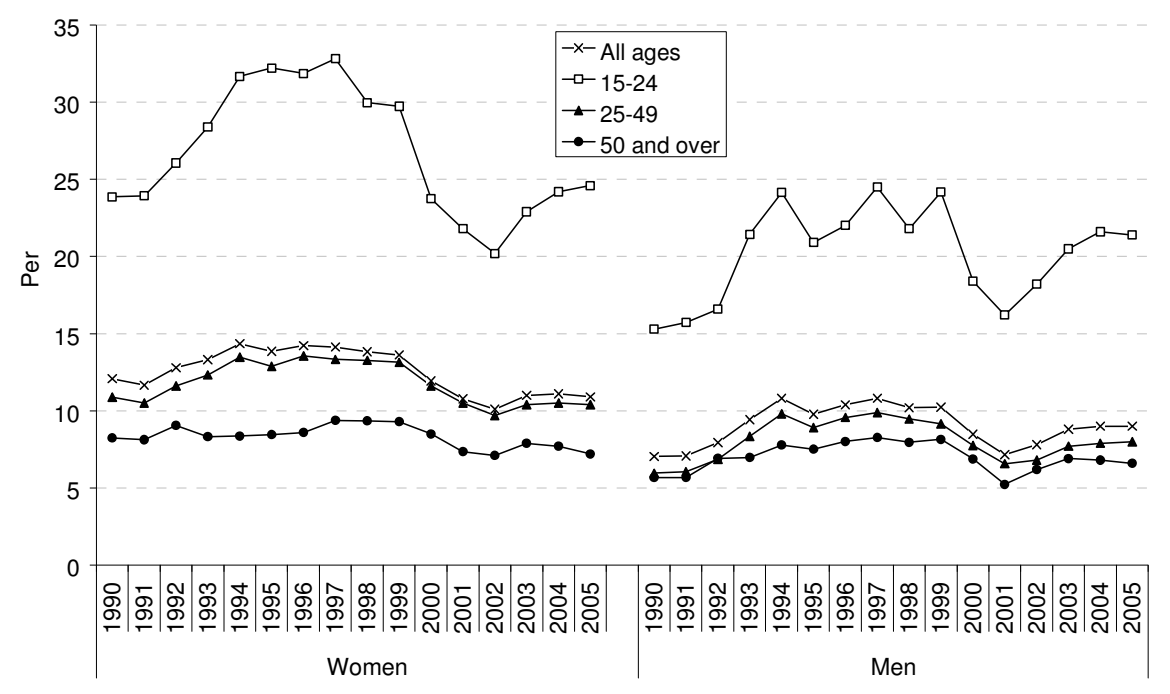

Source: INSEE, Employment surveys. http://www.insee.fr/fr/ffc/chifcle_fiche.asp?ref_id=NATCCF03302\&tab_id=313\&souspop=2

Despite there being many laws against gender discrimination at work, women's wages are, on average, 19\% lower than men's in private firms (INSEE, Employment surveys). Controlling for experience, time schedule, and other possible confounders leads to a remaining difference of $15 \%$. Among civil servants, the difference is around $14 \%$ (INSEE, 2004).

\subsection{Gender roles within family}

A Eurostat report on gender equity (Eurostat 2006b; Aliaga 2006) provides a number of comparative indicators on the gender division of domestic tasks. Because of women's lower activity rate compared to men and their greater propensity to work part-time, French women aged 20 to 74 spend, on average, less time each day $(2 \mathrm{~h} 31 \mathrm{~m})$ than men $(4 \mathrm{~h} 03 \mathrm{~m}$ ) in employment (or studying). However, women spend $4 \mathrm{~h} 30 \mathrm{~m}$ a day on domestic chores, compared with $2 \mathrm{~h} 22 \mathrm{~m}$ for men, a difference of $2 \mathrm{~h} 08 \mathrm{~m}$ a day, so that altogether, French women work $7 \mathrm{~h} 01 \mathrm{~m}$ a day and men only $6 \mathrm{~h} 25 \mathrm{~m}$. French men thus 
have an additional 38 minutes of leisure a day compared with women. Men's domestic time is spent on gardening, repairing, and shopping, while women spend more time preparing meals and cleaning.

French women are better off than Italian women (whose total working time is higher and who work one and a half hours more a day than men, and have an hour less leisure), but worse off than Swedish women (who work the same number of hours a day as men, and whose domestic work time exceeds that of men by 'only' one and a quarter hours).

\section{Social and population policies}

The most obvious explanation for France's relatively high fertility is its active family policy. We will consider family policies in a broad sense, in that we include social and public policies that may help to maintain high fertility. Indeed, some measures, with respect to such matters as education or housing, which were not designed to help families to have children, in fact have an effect on fertility ${ }^{7}$.

\subsection{Current consensus}

France has a long tradition of family policy. The State tends to stand in for families, with the aim of social equality as well as pro-natalism (Rosental 2003). French family policy is the result of the centuries-long political will of an early-formed central state to affirm itself against the power of the Catholic Church (Commaille and Martin 1998; Commaille, Strobel, and Villac 2002; Strobel 2004). By regulating the family sphere, the Republican state sought to beat the Church on its preferred ground and affirm its own power. These efforts were aided at the end of the 19th century by a strong pronatalist movement that stemmed from the early end of the historical fertility transition in France and the country's defeat in the 1870 war against Germany (Rosental 2003). The family policy that was finally implemented after the Second World War was a compromise between a Catholic vision of the family and more progressive ideals of social equality. For example, the entire policy was based on the male breadwinner and female caregiver pattern, but the development of kindergartens, introduced at the same time, was meant to promote equal opportunities among French children. Family policy

\footnotetext{
${ }^{7}$ Some companies' practices may also be included in 'family policies'. Some firms give allowances or provide care facilities, and reinstate young mothers easily after parental leave. However, a discussion of these matters lies beyond the scope of this paper.
} 
has always been a tool for regulating women's place between the private and work spheres, and has been connected with employment policy (Commaille, Strobel, and Villac 2002). From the 1930s to the 1960s, this policy reinforced the pattern of the nonworking mother, because family allowance was paid from the first child when the woman did not work. The policy was adapted further in the 1980s to accommodate the massive influx of women into the labour market. Collective and private care arrangements were developed for children under three, which helped women to reconcile family and work with almost no increase in men's participation in childcare.

Current French family policy is a result of a compromise between various political trends. The yearly Conférence de la famille is the place where new family policy measures are set out. Extensive dialogue with family movement associations, social protection bodies, union and management elected representatives, and experts precedes this conference. Religious institutions play a rather minor role.

This intervention of the State in the private sphere has long been accepted as legitimate. The State is perceived as the main stakeholder responsible for children (Letablier, Pennec, and Büttner 2003). The consensus on the importance of the family and State intervention goes beyond the political divide between right and left. However, there are divergences. Left-wing parties consider that family policy should be directed towards the poorest and adapt to changes in the family and behaviour. Considerations of gender equality have recently been advanced. Right-wing parties exhibit their pronatalist views more openly. Family policy should allow women to both raise their children and have more children. Moreover, right-wing parties argue for universal coverage for family policy, which should be distinguished from social policy.

In spite of a relatively high level of fertility compared with other European countries, the probirth tendency is still present in the political arena. It is more present in right-wing parties, but it is also deeply rooted in some left-wing parties. This tendency expresses both family and collective morality, and is more rationalistic than religious (Büttner, Letablier, and Pennec 2002). Its supporters are still anxious about the insufficient replacement of generations, and argue for increased support for families, particularly large families (Godet and Sullerot 2006; Franco 2006).

Current concerns have shifted gradually from the number of births to reconciling work and family (Ministère de la famille, 2005). Family policy is designed to encourage mothers' 'free choice' to continue to work or to stop working to raise their children. The idea is that women should not be penalized, whatever their choice, and that public policies should help women to have their desired number of children. 


\subsection{Mix of tools}

France has a rather generous and diversified family benefit system. Public expenditure on the family is quite high. According to Eurostat data, it was 2.8\% of the GDP in 2003, which is higher than the EU-25 average (2.1\%), behind only Denmark, Sweden, Finland, Luxemburg, and Germany. However, the Eurostat nomenclature does not take into account all benefits for families (such as the quotient familial or early schooling). Including fiscal support for families, the State contribution is estimated to be $3.6 \%$ of the GDP. Hence, France may be seen as the European country with the most substantial family policy (Adema and Ladaique 2005).

The originality of French family policy is that it mixes probirth objectives and objectives of family assistance (Hantrais and Letablier 1996). This compromise between promoting families versus promoting the work-family balance and women's employment has repercussions for the types of measure offered to families (see Appendix 1 for a summary of legal family benefits).

\subsubsection{Measures encouraging women's employment}

Since the 1970s, a whole range of facilities, services, and allowances linked with working status have accompanied increasing female participation in the labour force. First, the early socialization of children through crèches and écoles maternelles or nursery schools is encouraged. The number of crèches has increased since 1983. Crèche fees are means-tested and parents may also claim tax deductions. Unlike in Northern countries, this type of care is available immediately after the end of maternity leave, i.e. from when the baby is two or three months old, and the hours covered are extensive: on weekdays from 7:00-8:00 to 18:00-19:00. The école maternelle is a specifically French institution created in 1881 and enlarged during the 1970s and 1980s, during which period the number of places doubled. This service is available from the age of two, is free of charge, and is of high quality. The stated objective of this form of early collective socialization is not to allow women to combine motherhood and work, but to ensure equal opportunities to children, whatever their social class, in accordance with the French Republican secular tradition. Nevertheless, in practice this service helps mothers to reconcile family and work. The hours are long: School hours are from 8:30 to $16: 30$ for children aged 3 to 11 and care facilities are provided before and after school hours from 7:00 to 8:30 and from 16:30 to 18:00-19:00. Seventeen percent of children aged two to six use these facilities after school. Moreover, care facilities and school meals are available during lunchtime. Wednesday is a school-free day, but 
'leisure centres' take over. In 2002, 37\% of children aged two were enrolled and $97 \%$ at age three, despite the fact that this schooling is not compulsory (Blanpain 2006).

France dedicates only one quarter of its family expenditure to in-kind benefits and the share of cash benefit has grown over the years. As childcare facilities are costly and in order to create employment, private systems that are more individualized and flexible have been developed. Subsidized child-minders, allowances, and tax deductions have become new tools of family policy. Since 1980, an allowance paid to families with children under three (and then six) years old who are cared for at the home of a registered childminder has significantly reduced childcare costs. In 1986, another allowance was introduced for families who employ nannies to look after their children in the family home. Moreover, parents could deduct half of the cost incurred from their income tax. Some $70 \%$ of the total cost of childcare may be covered (Fagnani 1998). Moreover, families who employ someone to look after their children after school or on Wednesday may claim tax deductions (the chèque emploi service universel). Finally, according to a recent survey on child care, on weekdays, $61 \%$ of children under three years of age are cared for mainly by their parents, $21 \%$ by subsidized child-minders, $10 \%$ in a crèche, $7 \%$ by their grand-parents or family, and $1 \%$ by nannies at home (Blanpain 2006; Ruault and Daniel 2003).

In 1994, the family policy came to a crossroads. The reform of family policy, which had been implemented in a context of high unemployment, had the opposite intention of creating incentives to leave the labour force. The Allocation parentale d'éducation (APE) was designed to allow one of the parents (in practice, mothers) to devote themselves entirely to bringing up the newborn child until its third birthday. For a period of three years after a birth of order 3 or more, a fixed amount of money is given to a parent who stops working to raise their youngest child. Parents who decide to work part-time receive a partial allocation. This allocation has existed since 1985, but before 1994 it was available only after the third child. In 1994, it was made available to parents of a second child. Its goal was mainly to reduce public expenditure. In 2004, all existing infancy benefits were unified into a single one: the Prestation d'accueil du jeune enfant (PAJE). The APE was replaced by the Complément libre choix d'activité de la Prestation d'accueil du jeune enfant (PAJE) and was made available for the first child for six months after birth ${ }^{8}$. A debate arose regarding the need to encourage highincome men and women to be entitled to the leave and to reduce its negative effect on the career path. So, since 2006, parents of 3 children have been able to choose to have a one-year leave and receive a higher benefit or a three-year leave and receive a lower

\footnotetext{
${ }^{8}$ Both entitlement conditions and benefits amounts remained unchanged, except for the mothers of a first child.
} 
benefit. As we have seen before, this measure has been a success, even if the take-up rate is far behind those in Northern countries.

\subsubsection{Measures encouraging large families}

Beyond the measures that aim to reduce tensions between work and family, several measures have been designed to reduce the cost of children, since the end of the Second World War. As in Southern countries, these allowances are directed specifically towards families that have three or more children (Breton and Prioux 2005). They vary with the age of the children. Universal family benefits are available, but in France they are available only from the second child and are progressive. For instance, the allowances paid for families that have three children are 2.3 times higher than those for families that have two children. They are 3.6 times higher for families that have four children. Several means-tested allowances are also available as the core allowance of PAJE for families that have at least one child under three. The complément familial is substituted for these allowances for families that have at least three children when the youngest reaches the age of three. A means-tested allowance is also dedicated to single mothers until the youngest child reaches the age of three. On the other hand, a special tax rule named quotient familial favours families that have at least three children and that pay tax. The French tax system is not individual-based but family-based and from the third child, each additional child counts for one tax unit (instead of one half before), which leads to significant tax deductions. This measure is a purely probirth one ${ }^{9}$.

\subsubsection{Other social policy measures}

Other measures of social policy, which are not directly targeted at 'family' or 'maternity' risks, create transfers towards households according to their composition. For instance, the situation of the family has been taken in account in housing policies since 1948 (Aglietta, Blanchet, and Héran 2003). Some basic welfare benefits also take into account the number of children.

\footnotetext{
${ }^{9}$ Income tax is not paid by individuals, but by households. The members of the household sum their incomes and the tax rate is computed from the ratio of the total income to the number of tax units (parts). For a married or a "Pacsed" couple, each spouse counts for one unit, the first and second children for half a unit, and the subsequent children for one full unit. Unmarried couples cannot merge their incomes and tax units; the children living with the couple must be attributed to one or other of the partners. Lone parents (but not unmarried couples) are allowed to count each child for one full unit.
} 
Finally, French family policy is a mix of many tools: No fewer than 28 different measures are aimed at the family (Aglietta, Blanchet, and Héran 2003; Godet and Sullerot 2005; Algava and Bressé 2005). It combines 'horizontal' redistribution towards families that have the same standard of living (from people living alone or with no children to families, in order to 'compensate' for the cost of childrearing) with 'vertical' redistribution towards the poorest (Bechtel et al. 2005a).

The complexity of family policy measures makes any evaluation almost impossible, because the specific effect of each measure is mixed with other effects. All in all, the government adapts policy measures or creates new ones (each year the Conference de la famille is the occasion for a specific announcement). The family policy gives the impression that the State helps all families, irrespective of their way of life and their standard of living. In 1997, the then socialist government decided to means-test family allowances. In practice, this involved only the $2 \%$ of households that had the highest income, but there was wide opposition to this measure, on the grounds that the allowances had to remain universal. In 1998, the government made the allowances universal again, but restricted the advantage gained from the quotient familial. In purely financial terms, the two measures were very similar, but the latter was well received, because it limited an income tax reduction, while the former was refused, because it went against the dogma of universal family allowances.

However, the net level of allowances has fallen over the years, due to inflation and increasing expenditure on the elderly (Thélot and Villac 1998). The probirth objective is weaker, but still present. Unlike in Scandinavian countries, the objective of gender equality is rather low on the agenda. Family policy is directed only towards mothers, because reconciling work and family is women's business (Commaille, Strobel, and Villac 2002). The goal of gender equality within the family was not raised until very recently. The 'socialist' population policy in 1997-2002 aimed to introduce a 'feminist' family policy that would help both parents to reconcile work and family. This took the form of statutory paternal childcare leave in 2002. This measure is rather timid (its maximum duration is 11 days) but has been a success: Right from the beginning, $60 \%$ of fathers took this leave.

\subsection{Effect of family policies on fertility}

Family benefits reduce the cost of having children; hence, it may be expected that the relationship between family policy and fertility would be positive. Measuring the impact on fertility is complex and very sensitive to the method and data used. One can measure the short-term effects of policies, whereas long-term trends are more difficult to evaluate. These long-term trends depend more on a favourable context to families 
than on specific family policies. So, studies generally find that direct cash benefits are positively related to fertility, but that the effect appears to be small (Gauthier and Hatzius 1997; Ekert-Jaffé 1986). For instance, French family benefits are estimated to increase fertility by 0.2 children per woman on average (Blanchet and Ekert-Jaffé 1994). The targeting of family allowances on families with three or more children also has a clear effect on the progression to third births and the timing of births in France (Ekert-Jaffé et al. 2002; Breton and Prioux, 2005), but the effect is small. Moreover, family policies tend to erase the fertility differential by social class (Ekert-Jaffé et al. 2002).

The changes in the rules concerning the APE, particularly its extension to parents of two children in 1994, may be viewed as a sort of 'natural experiment' on the impact of such an allowance on fertility and women's professional activity. The direct impact on fertility is very limited, while the effect on female participation in the labour force is large. Estimated by the 'difference in difference' method, estimates give the following orders of magnitude, for some 200,000 women with a full time allowance: Around 100,000 women would have stopped working in any case after the birth of their second child, even without the APE, and the annual number of births may have increased by some 12,000 because of the change in behaviour due to the APE (Piketty 2005), i.e. $1.6 \%$ of yearly births. This effect is smaller than current fluctuations from one year to another. Using a micro-simulation model, Laroque and Salanié (2005) also conclude that financial incentives play a rather modest role in fertility decisions. They estimate that the extension of the APE to second births has caused parity 2 births to increase by $11 \%$, but has caused parity 3 births to fall by around 3\%. However, their model does not take into account timing effects and probably overestimates the impact in the long run. Between 1994 and 2000, the number of births in France increased by 63,000, from 711,000 to 774,000 , and the change in the APE is surely not the cause of such a large change.

Thus, the continuing increase in the TFR since 1995 (see Figure 1 above) may not be simply related to any specific policy measure. Fertility rates at ages below 25 are stable, which could be related to the stable age at the end of studies since 1995 (Durier 2006), while fertility rates at higher ages are still increasing at the same pace. In any case, since 1975, the overall level of fertility has been almost stable. The French family policy, by contrast, changes continually. On the one hand, most measures are priceindexed, so their weight in the GNP is structurally decreasing; on the other hand, new measures are introduced yearly, and the conference de la famille is organized explicitly to emphasize the fact that the State wants to help the families, by showcasing new measures that are implemented (Bechtel et al. 2005b). This 'mix of tools' is very likely related to the current high fertility in France, but it is very difficult to quantify the overall effect. 


\subsection{Other current demographic questions}

At the government level, the demographic target recently shifted partially, to a family model that combines high fertility with high female participation in the labour force (Ministère de la famille, 2005). As a result of this shift, the criteria for evaluating family policy in France, such as the recent changes in parental leave allowance, may take into account not only the trends in the number of births, but also other consequences, particularly with respect to female participation in the labour force, because some measures would facilitate women's work, while others would facilitate their withdrawal from the employment market.

The question of retirement is now coming to the fore (Conseil d'orientation des retraites, 2005), with a specific focus on gender equality. As a result of increasing female participation in the labour force, differences between men and women in retirement pensions are becoming smaller. The delay in widowhood leads to an increase in old peoples' standard of living, but there is now a tension between the individualization of social rights (social policies being oriented towards individuals) and the fact that women receive more derived pensions (when widowed or divorced) than men. The rule in the case of a person who has been married more than once is currently a share of the derived pension proportional to the duration of marriage. The issue of how individuals and families relate to the State remains open in France.

Last but not least, questions about net migration (selection of immigrants, integration of new migrants) and the integration of inhabitants of foreign origin (immigrants' children and grand-children) are raised in the context of a long history of immigration in France, with a current moderate level of net migration.

Concern about the level of fertility is nevertheless still present, and the fear of fertility decline is always cited in the political texts on family policy. Two recent information reports from Parliament continue this trend, which is by no means a new one in France. The first (Pavy 2006) acknowledges the fact that the current level of fertility is 'not too unfavourable' and that current issues (ageing, youth unemployment, future labour force shortage) are not directly linked to the fertility level, but at the same time refers to the fact that 'Putting right the level of fertility appears to be a necessary answer to the long term consequences of ageing'. The second deals with the current level of fertility at the European level, with a strong pronatalist approach (Franco 2006).

\section{Attitudes towards childbearing in France}

It can be argued that French family policy contributes substantially to maintaining a high level of fertility in the country by concretely helping women to reconcile work and 
family life. Those policies may also promote fertility more indirectly, by creating a child-friendly environment that encourages individuals to have positive attitudes towards childbearing and to have children, even when they do not benefit from state support.

\subsection{Fertility intentions}

A family of two to three children is the largely dominating ideal in France today (Toulemon and Leridon 1999). Almost half of women aged 15 to 45 in a survey conducted in 1998 think that two is the ideal number of children, while almost four out of 10 people think that three is ideal. References to family sizes smaller than two are rare. A recent analysis of Eurobarometer data (Testa and Grilli 2006) that included individual and regional level factors shows that, regarding the perceived ideal number of children among people who want at least one child, French people rank second just behind Ireland, with an average ideal number of children of 2.34. The unexplained contextual residual is positive and rather high, and spread evenly across all regions of France. In other words, the ideals expressed by French people would be lower if they were based only on the individual and contextual variables introduced in the model (which includes the fertility level at the regional level). An especially positive and widely-shared attitude towards a high number of children (three-child families) seems to have been nurtured by the multi-facetted French family policy, which promotes in the same breath progressive state-run child care, conservative gender relations, and pronatalist ideals across the board. As we saw, higher social classes champion large family sizes in France, which is another sign of the positive attitudes towards large (three-child) families prevailing in this country.

Few French people do not want children. Ninety-five percent of them want at least one child according to the Eurobarometer data source, which is very similar to the high proportion found in all the other European countries (Nordic, Southern, Englishspeaking), except in continental Europe (German-speaking countries, the Netherlands, Belgium), where only between $81 \%$ and $91 \%$ of people want children. The proportion of French people who want at least one child is not fully explained by individual factors (sex, educational level, age, marital situation, number of adults in the household) and contextual factors (proportion of childless people, and average mean individual variables) introduced into the model: A positive residual is observed in the South of France. The issue of what could explain the more accentuated dislike of childlessness among inhabitants of the Southern region of France is an interesting one. 


\section{2 'Family cultural divide' runs through France}

For Reher (1998), the Scandinavian countries, much of Germany and Austria, the United Kingdom, the Netherlands, and the United States are all historically characterized by weak family ties, as opposed to Southern European countries, where family ties are stronger. This historical difference is supposed to go back to mediaeval times, when the North of Europe was socially organized around tribes, and Southern European societies, influenced by their Muslim neighbours, were built on an extended family system. As a result of that cultural divide, the Reformation and the Industrial Revolution took a deeper hold in the North of Europe and contributed to widening it. France lies in the middle of the divide, with its Northern region being more individualistic and the Southern region being more family-oriented. The same holds true for Germany and Austria.

Reher (1998) argues that these differences prevail today. To make his point, he maintains that Southern family-oriented societies are more conservative morally and less dynamic economically, and that they also have fewer homeless people, less suicide, and less loneliness. One could argue that although family ties are not more numerous nor more exchange-intensive in the South of Europe, they may still be more unconditional. Being intrinsically non-optional, these family ties may still act as a social safety net. This factor could explain why almost all people in the southern countries of Europe still want a child, which is not the case in German-speaking countries, where, as in Southern countries, state support for managing work and child care is relatively weak. It could also explain the greater propensity, compared to other regions, showed by inhabitants of the south of France to say that they want to have at least one child.

Caring for dependants within the family comes at a price: the subordinate position of women and a greater domestic burden. In a context where most women work, state support seems to be the crucial factor in the intensity of exchanges between family members. This is not true just for fertility. Research on intergenerational family relations seems to show that time and money exchanges between generations is greater in the Nordic and continental European countries, which offer greater state support to their elderly population, than in Southern European countries, although intergenerational cohabitation remains more frequent in the South (Attias-Donfut $e t$ al. 2005). Thanks to state help, older people with pensions can give money to their younger family members, while younger family members can care for older people who stay at home. Attias-Dunfut $e t$ al. conclude that state support and personal investments in family ties go hand in hand in societies where women participate in the labour force. 


\section{Conclusion}

Fertility remains relatively high in France, despite the tendency of young people, as elsewhere in Europe, to delay their entry into parenthood, the growing unpopularity of marriage, the spread of medical contraception, and a quite considerable use of abortion. The main reason for high fertility in France, by European standards, is the high level of fertility rates between the ages of 30 and 40, when most women are working. France has experienced almost the same demographic and social changes in family behaviour as other countries, but fertility has remained stable, because women manage to have children without being married and continue to work (or return to work after a short time) after each birth.

Unlike other European countries, the current level of fertility is associated with a long-term stationary population. Taking into account the relatively low level of net migration, net reproduction is near 1 , so that there is no obvious need for any pronatalist action if population stationarity is considered to be a suitable long-term aim.

Fertility has remained high in France for the following reasons. The country has pursued an active multi-facetted family policy since the Second World War (with egalitarian, conservative, and pronatalist components) and was reinforced in the 1980s. The policy enjoys a wide consensus among politicians as well as French residents and in practice helps women (but not men) to reconcile work and family roles. As a consequence, the two- or three-child family is still an ideal in France. Current main social and economic issues concern 'non-purely-demographic' problems: high unemployment, high long-term unemployment, (especially among young people and older workers), and higher unemployment for women. Many laws on gender equality and parity in politics have been passed in France but not applied in practice. Increasing flexibility with respect to time schedules, forced part-time work, and flexible hours may be more concentrated on women, thus increasing their burden. As feminist demands grow louder, French family policy may have to make room for one more ideological strain and help fathers to become more involved with their families. 


\section{References}

Adema Willem, and Maxime Ladaique. 2005. "Net social expenditure - 2005 Edition. More comprehensive measures of social support", OECD Social, Employment and Migration Working Papers 29.

Afsa Cédric. 1998. "L'allocation parentale d'éducation : entre politique familiale et politique pour l'emploi", INSEE-Première 569.

Aglietta Michel, Didier Blanchet, and François Héran. 2002. Démographie et économie, Rapports $\mathrm{du}$ Conseil d'analyse économique 35. Paris: La documentation française, $340 \mathrm{p}$. http://www.ladocumentationfrancaise.fr/rapports-publics/024000104/index.shtml.

Algava Elisabeth, and Sophie Bressé. 2005. "Les bénéficiaires de l'Allocation parentale d'éducation : trajectoires d'activité et retour à l'emploi", Études et résultats 399. http://www.sante.gouv.fr/drees/etude-resultat/er399/er399.pdf.

Aliaga Christel. 2005. "Gender gaps in the reconciliation between work and family life", Statistics in focus, Eurostat, 4/2005. www.eustatistics.gov.uk/Download.asp?KS-NK-05004-EN_tcm90-18860.pdf.

Aliaga Christel. 2006. "How is the time of women and men distributed in Europe", Statistics in focus, Eurostat, 4/2006. http://epp.eurostat.cec.eu.int/cache/ITY_OFFPUB/KS-NK-06004/EN/KS-NK-06-004-EN.PDF.

Anttonen Anneli, and Jorma Sipila. 1996. "European social care services: is it possible to identify models?", Journal of European Social Policy 6/2: 87-100.

Attias-Donfut Claudine, Nicole Lapierre, and Martine Segalen. 2002. Le nouvel esprit de famille. Paris: O. Jacob.

Attias-Donfut Claudine, Jim Ogg, and François-Charles Wolff. 2005. "European patterns of intergenerational financial and time transfers", European Journal of Ageing 2: 161-173.

Bajos Nathalie, Henri Leridon, and Nadine Job-Spira. 2004. "La contraception et le recours à l'avortement en France dans les années 2000 : présentation et premiers résultats de l'enquête Cocon : introduction au dossier", Population 59(3-4): 409-418.

Beaumel Catherine, Fabienne Daguet, Lucile Richet-Mastain, and Mauricette Vatan. 2006. La situation démographique en 2004 - Mouvement de la population. Insee Résultats 55 soc. http://www.insee.fr/fr/ppp/ir/accueil.asp?page=sd2004/ accueil.htm.

Bechtel Julien, Laurent Caussat, Pierre Courtioux, Nadine Laib, Sylvie Le Minez, and Benoît Mirouse. 2005a. "La politique familiale française : coûts et bénéficiaires", Complement $\mathrm{n}^{\circ} \mathrm{J}$ in Godet, Sullerot 2005.

Bechtel Julien, Laurent Caussat, Nadine Laib, Sylvie Le Minez, and Benoît Mirouse. 2005b. "les transferts sociaux en faveur des familles : une évaluation macro-économique", Études et résultats 376. http://www.sante.gouv.fr/drees/etude-resultat/er-pdf/er376.pdf.

Billari Francesco, and Hans-Peter Kohler. 2004. "Patterns of low and lowest-low fertility in Europe", Population studies 58(2): 161-176.

Blanchet Didier, and Olivia Ekert-Jaffé. 1994. "The demographic impact of family benefits: evidence from a micro-model and from macro-data", in Ermish John, and Nashiro Ogawa (eds), The Family, the Market and the State in Ageing Societies. Oxford: Clarenton Press: 79-103. 
Blanpain Nathalie. 2006. "Scolarisation et modes de garde des enfants âgés de 2 à 6 ans", Études et résultats 497. http://www.sante.gouv.fr/drees/etude-resultat/er497/er497.pdf.

Blayo Chantal. 1995. "L'évolution du recours à l'avortement en France depuis 1976", Population 50(3): 779-810.

Bongaarts John. 2001. "Fertility and reproductive preferences in post-transitional societies", Population and Development Review 27, Supplement: Global fertility transition: 260-281.

Bonnet Carole, and Morgane Labbé. 1999. "L'activité professionnelle des femmes après la naissance de leurs deux premiers enfants : l'impact de l'allocation parentale d'éducation", Études et résultats 37. http://www.sante.gouv.fr/drees/etude-resultat/er-pdf/er037.pdf.

Breton Didier, and France Prioux. 2005. "Two Children or Three? Influence of Family Policy and Sociodemographic Factors", Population-E 60(4): 415-445.

Büttner Olivier, Marie-Thérèse Letablier, and Sophie Pennec. 2002. "L'action publique face aux transformations de la famille en France", rapport de recherche du CEE, 02.

Caldwell John C., and Thomas Schindlmayr. 2003. "Explanations of the fertility crisis in modern societies: a research for commonalities." Population Studies 57(3): 241-263.

Cassan Francine, François Héran, and Laurent Toulemon. 2000. "Study of Family History. France's 1999 Family Survey", Courrier des statistiques, English series 6, 2000 annual issue: 7-19. http://www-ehf.ined.fr/english/english/C_stat_en.pdf

Caussat Laurent. 2006. "Fertility trends and family friendly policy in France: do they match?", proceedings of the Policy Forum on Low Fertility and Ageing Society (Facing the future: policy challenges in the ageing era), Seoul, 13 - 14 September.

Chambaz Christine. 2001. "Les jeunes adultes en Europe: independence résidentielle, activités, resources", Recherche et previsions 68, "Jeunes adultes".

Conseil d'orientation des retraites. 2006. Retraites : droits individuels et droits famililiaux, la recherche de l'égalité entre hommes et femmes. Actes du colloque 15 décembre 2005. Paris: La documentation française.

Commaille Jacques, and Claude Martin. 1998. Les enjeux politiques de la famille. Paris: Bayard.

Commaille Jacques, Pierre Strobel, and Michel Villac. 2002. La politique de la famille. Paris: La Découverte.

Daguet Fabienne. 2002. Un siècle de fécondité française : caractéristiques et évolution de la fécondité de 1901 à 1999. Insee Résultats. Société 8.

Del Boca Daniela, Silvia Pasqua, and Chiara Pronzato. 2004. "Why are fertility and women's employment rates so low in Italy? Lessons from France and the UK", IZA Discussion Paper 1274.

Durier Sébastien. 2006. "Les progrès de la scolarisation des jeunes de 1985 à 2003". INSEE, Données Sociales: 95-100, http://www.insee.fr/fr/ffc/docs_ffc/DONSOC06j.PDF.

Ekert-Jaffé Olivia. 1986. "Effets et limites des aides financiers aux familles : une expérience et un modèle", Population 41(2): 327-348.

Ekert-Jaffé Olivia, Heather Joshi, Kevin Lynch, Rémi Mougin, Mickael Rendall, and David Shapiro. 2002. "Fertility, timing of births and socio-economic status in France and Britain: social policies and occupational polarisation”, Population-E 57(3): 475-507.

Esping-Andersen Gosta. 1990. The three worlds of welfare capitalism. Cambridge: Polity Press.

Esping-Andersen Gosta. 1999. Social foundations of postindustrial economies. Oxford: Oxford University Press. 
Eurostat. 2006a. First demographic estimates for 2005, Statistics in focus. Population and Social conditions $\quad 1 . \quad$ http://epp.eurostat.ec.europa.eu/cache/ITY_OFFPUB/KS-NK-06001/EN/KS-NK-06-001-EN.PDF.

Eurostat. 2006b. "8 March 2006: International Women's Day. A statistical view of the life of women and men in the EU25", Eurostat News Release, 29/2006, 6 March. http://epp.eurostat.ec.europa.eu/pls/portal/docs/PAGE/PGP_PRD_CAT_PREREL/PGE_ CAT_PREREL_YEAR_2006/PGE_CAT_PREREL_YEAR_2006_MONTH_03/306032006-EN-BP1.PDF, August 5th 2006.

Fagnani Jeanne. 1998. "Recent changes in family policy in France: Political trade-offs and economic constraints", in Drew Eileen, Emerk Ruth, Mahon Evelyn (eds), Women, work and the family in Europe. London/New-York, Routledge: 58-65.

Ferrand Michèle. 2004. Féminin masculin. Paris : La Découverte.

Festy, Patrick. 2001. "The "Civil Solidarity Pact" (PACS) in France: an impossible evaluation", Population and Societies 369.

Franco Arlette. 2006. Les changements démographiques et la nouvelle solidarité entre générations. Rapport d'information de l'Assemblée nationale, déposé par la délégation de l'Assemblée nationale pour l'Union européenne. http://www.assembleenationale.fr/12/europe/rap-info/i2887.asp.

Frejka Tomas, and Jean-Paul Sardon. 2006. "First birth trends in developed countries. Persisting parenthood postponement", Demographic Research 15(6): 147-180. http://www.demographic-research.org/volumes/vol15/6/

Fürnkranz-Prskawetz Alexia, Henriette Engelhart, and Marija Mamolo. 2005. "A pooled time series analysis on the relation between fertility and key fertility-related demographic behavior across space and time", Presented at the Conference on Postponement of Childbearing in Europe, Vienna, December 2005.

Gauthier Anne H., and Jan Hatzius. 1997. "Family benefits and fertility: an econometric analysis", Population studies 51(3): 295-306.

Godelier Maurice. 2004. Métamorphoses de la parenté. Paris: Fayard.

Godet Michel, and Évelyne Sullerot. 2005. La famille, une affaire publique. Rapports du Conseil d'analyse économique 35. Paris: La documentation française, $340 \mathrm{p}$. http://lesrapports.ladocumentationfrancaise.fr/BRP/054000761/0000.pdf.

Gornick Janet, Marcia Meyers, and Katherin Ross. 1997. "Supporting the employment of mothers: policy variation across fourteen welfare states", Journal of European Social Policy 7(1): 45-70

Hantrais Linda, and Marie-Thérèse Letablier. 1996. Families and family policies in Europe. London: Longman.

Hantrais Linda. 2004. Family policy matters; responding to family change in Europe. Bristol: The Policy Press.

Henshaw Stanley K, Susheela Singh, and Taylor Haas. 1999. "The incidence of abortion worldwide", International family planning perspectives 25(Supplement): S30-S38.

Hoem Britta. 1996. "The social meaning of the age at second birth for third-birth fertility: a methodological note on the need to sometimes respecify an intermediate variable", Yearbook of Population research in Finland 33: 333-339.

INSEE. 2004. Femmes et hommes. Regards sur la parité. An updated version of the tables and graphs is available at http://www.insee.fr/fr/ffc/docs_ffc/femmes_et_hommes.asp. 
INSEE. 2007. France in Facts and figures. The French population. http://www.insee.fr/ en/ffc/pop_age.htm.

Kafé Hélène, and Nicolas Brouard. 2000. "Teenage pregnancies in France : what has changed in the last twenty years?", Population and Societies 361.

Kaufmann Jean-Claude. 2004. L'invention de soi : une théorie de l'identité. Paris: A. Colin.

Kieffer Annick, Catherine Marry, Monique Meron, and Anne Solaz. 2005. "The case of France : family formation in an uncertain labor market". In: Blossfeld Hans-Peter, Eric Klijzing, Melinda Mills, and Karin Kurz (eds). Globalization, uncertainty and youth in society. London: Routledge: 105-134.

Kohler Hans-Peter, and Jose Antonio Ortega. 2006. "Low and lowest-low fertility in Europe: Causes, implications and policy options", PAA annual meeting, Los Angeles, 30 March-2 April 2006.

Laroque Guy, and Bernard Salanié. 2004. "Does fertility respond to financial incentives", working paper available at http://www.crest.fr/pageperso/salanie/p140205.pdf.

Lefèvre Cécile, and Alexandra Filhon (eds). 2005. Histoires de familles, histoires familiales. Les résultats de l'enquête Famille de 1999. Les Cahiers de l'INED 156. Paris: INED, XXXVIII+642 p.

Legros Francoise. 2003. "La fécondité des étrangères en France : une stabilisation entre 1990 et 1999”, INSEE première 898. http://www.insee.fr/fr/ffc/docs_ffc/IP898.pdf.

Leridon Henri, Yves Charbit, Philippe Colomb, Jean-Paul Sardon, and Laurent Toulemon. 1987. La seconde révolution contraceptive. La régulation des naissances en France de 1950 à 1985. Les Cahiers de l'INED 117. Paris: PUF, 380 p.

Leridon Henri, Pascale Oustry, Nathalie Bajos, and the Cocon team. 2002. "The growing medicalization of contraception in France", Population and Societies 281. http://www.ined.fr/englishversion/publications/pop_et_soc/pesa381.pdf.

Lesthaeghe, Ron, and Johann Surkyn. 1988. "Cultural dynamics and economic theories of fertility change", Population and development review 14: 1-45.

Letablier Marie-Thérèse, Sophie Pennec, and Olivier Büttner. 2003. "Opinions, attitudes et aspirations des familles vis-à-vis de la politique familiale en France", Rapport de recherche du CEE 09, janvier.

Mahieu Ronan. 2005. "La PAJE après 18 mois de montée en charge", L'e-ssentiel 42, octobre 2005. http://www.cnaf.fr/web/WebCnaf.nsf/VueLien/E-SSENTIEL42?opendocument.

Marc Céline. 2004. "L'influence des conditions d'emploi sur le recours à l'APE", Recherches et previsions 75 : 21-38.

McDonald Peter. 2005. "Fertility and the State: the efficacy of policy". Paper presented at the XXVème congrès de l'Union Internationale pour l'Etude Scientifique de la Population, Tours, 18-23 juillet 2005.

Méda Dominique, Marie-Odile Simon, and Marie Wierinck. 2003. "Pourquoi certaines femmes s'arrêtent-elles de travailler à la naissance d'un enfant", Premières informations Premières synthèses 29.2. http://www.travail.gouv.fr/IMG/pdf/ publication_pips_200307_n-29-2_femmes-naissances-arret-travail.pdf.

Ministère de la famille. 2005. Conférence de la famille $2005:$ dossier d'information, $\mathrm{n}^{\circ} 1$ at the front of the Minister's website http://www.famille.gouv.fr/ during six months (from September 2005 to present march 2006), leading to http://www.famille.gouv.fr/doss_pr/conf_famille2005/dossier_presse_220905.pdf. 
Morgan S. Philip, and Miles G. Taylor. 2006. "Low Fertility at the Turn of the 21st Century", Annual Review of Sociology 32: 375-399.

Muñoz-Pérez Francisco, and France Prioux. 2000. "Children born outside marriage in France and their parents : recognitions and legitimations since 1965, Population, an English selection 12: $139-195$.

Neyer Gerda. 2003. "Family policies and low fertility in Western Europe", MPIDR working paper WP 2003-021.

Ní Bhrolcháin Máire, and Laurent Toulemon. 2005. "Does Postponement Explain the Trend to Later Childbearing in France?", Vienna Yearbook of Population Research 5: 83-108.

OECD. 2005. Evolution of female employment as a percentage of the female working-age population since 1980. www.oecd.org/; http://www.oecd.org/dataoecd/34/30/ 34542436.xls.

Pailhé Ariane, and Anne Solaz. 2006. "Employment and childbearing: women bear the burden of the work-family balance", Population and Societies 426. http://www.ined.fr/fichier/ t_publication/1207/publi_pdf1_pop_et_soc_francais_426.pdf.

Pavy Béatrice. 2006. Les perspectives démographiques de la France et de l'Europe à l'horizon 2030 : analyse économique. Rapport d'information de l'Assemblée nationale, déposé par la commission des finances, de l'économie générale et du plan. http://www.assembleenationale.fr/12/rap-info/i2831.asp.

Piketty Thomas. 2005. "L'impact de l'allocation parentale d'éducation sur l'activité féminine et la fécondité en France", chapter 4 in Lefèvre, Filhon. 2005: 79-109.

Prioux, France. 2003. "Age at first union in France: a two-stage process of change", Population-E 58(4-5): 559-578.

Prioux France. 2005. "Recent Demographic Developments in France", Population-E 60(4): 371 414.

Rallu Jean-Louis, and Laurent Toulemon. 1994. "Period fertility measures. The construction of different indices and their application to France", Population. An English Selection 6: 59130.

Reher David Sven. 1998. "Family ties in western Europe: persistent contrasts", Population and development review 2: 203-234.

Régnier-Loilier Arnaud. 2005. "Évolution des naissances et des grossesses non désirées en France. Réflexions méthodologiques et éléments d'interprétation". Paper presented at the XXVème congrès de l'Union Internationale pour l'Etude Scientifique de la Population, Tours, 18-23 juillet 2005.

Robert-Bobée, Isabelle. 2006. "Projections de population pour la France métropolitaine à l'horizon 2050 - La population continue de croître et le vieillissement se poursuit, INSEE première 1089. http://www.insee.fr/fr/ffc/ipweb/ip1089/ip1089.pdf.

Robert-Bobée Isabelle, and Magali Mazuy. 2005. "Calendriers de constitution des familles et âge de fin d'études", chapter 8 in Lefèvre, Filhon. 2005:175-200.

Rosental Paul-André. 2003. L'Intelligence démographique. Sciences et politiques des populations en France (1930-1960). Paris: Odile Jacob.

Rossier Clementine, Henri Leridon, and the Cocon group. 2004. "The pill and the condom, substitution or association? An analysis of the contraceptive histories of young women in France, 1978-2000", Population-E 59(3-4): 387-414.

Rossier Clémentine, and Claudine Pirus. 2007. "Estimating the number of abortions in France: 1976-2002”, Population-E 62(1): 57-88. 
Ruault Marie, and Daniel Audrey. 2003. "Les modes d'accueil des enfants de moins de 6 ans : premiers résultats de l'enquête réalisée en 2002", Études et résultats 235. http://www.sante.gouv.fr/drees/etude-resultat/er235/er235.pdf.

Sardon Jean-Paul. 2004. "Recent demographic trends in the developed countries", Population-E 59(2): 263-314.

Segalen Martine. 2000. Sociologie de la famille. Paris: A. Colin.

Singly de François. 1996. Le soi, le couple et la famille. Paris: Nathan.

Singly de François. 2000. Libres ensemble : l'individualisme dans la vie commune. Paris: Nathan.

Sobotka Tomas, Maria Winkler-Dworak, Maria Rita Testa, Wolfgang Lutz, Dimiter Philipov, Henriette Engelhardt, and Richard Gisser. 2005. "Monthly Estimates of the Quantum of Fertility: Towards a Fertility Monitoring System in Austria", Vienna Yearbook of Population Research 2005: 109-141. Supplementary Appendices available in electronic form at the Yearbook's Internet link: http://www.oeaw.ac.at/vid/p_yearbook.shtml.

Strobel Pierre. 2004. "L'Etat et les transformations de la famille", in: Familles et politiques familiales, Cahiers Français 322: 57-64.

Testa Maria Rita, and Leonardo Grilli. 2006. "The influence of childbearing regional contexts on ideal family size in Europe, Population-E 61(1-2): 109-137.

Thélot Claude, and Michel Villac. 1998. Politique familiale. Bilan et perspectives. Rapport à la ministre de l'emploi et de la solidarité et au ministre de l'économie, des finances et de l'industrie. Paris: La Documentation Française.

Toulemon Laurent. 2006. "Fertility Among Immigrant Women and Men in France: New Data, a New Approach", Presented at the Population Association of American 2006 Annual Meeting, Los Angeles, California, March 30-April 1, 2006. Session 102: New Ways of Looking at Fertility Measurement Challenges, 19 p. http://paa2006.princeton.edu/ download.aspx? submissionId=61103.

Toulemon Laurent. 2003. La fécondité en France depuis 25 ans, rapport au Haut conseil de la population et de la famille, 77 p. http://www.ladocumentationfrancaise.fr/rapportspublics/034000116/index.shtml.

Toulemon Laurent. 2001. "How many children and how many siblings in France in the last century?", Population and Societies 374. http://www.ined.fr/fichier/t_publication/ 539/publi_pdf2_pop_and_soc_english_374.pdf.

Toulemon Laurent. 1997. "Cohabitation is here to stay", Population. An English Selection 9: 1146.

Toulemon Laurent, and Lisbeth Knudsen. 2006. "Stepfamilies in Denmark and France. Does the number of previous children from both partners and whether the previous children live with the couple influence fertility?". Presented at the Population Association of American 2006 Annual Meeting, Los Angeles, California, March 30-April 1, 2006. Session 176: Multi-partnered Fertility, 26 p.

Toulemon Laurent, and Henri Leridon. 1991. "Vingt années de contraception en France: 19681988", Population 46(4): 777-812.

Toulemon Laurent, and Henri Leridon. 1999. "La famille idéale : combien d'enfants, à quel âge ?", Insee première 652. http://www.insee.fr/fr/ffc/docs_ffc/IP652.pdf.

Toulemon Laurent, and Magali Mazuy. 2001. "Les naissances sont retardées mais la fécondité est stable", Population 56(4): 611-644. 
Toulemon Laurent, and Isabelle Robert-Bobée. 2006. "The French population projected to level off at 70 million", Population and Societies 429. http://www.ined.fr/fichier/ t_publication/1221/publi_pdf2_pop_soc_english_429.pdf.

United Nations. 2003. World Population Prospects: The 2002 Revision.

Vilain Annick. 2005. "Les interruptions de grossesse en 2003, Études et Résultats 431.

Van de Kaa Dirk. 1987. "Europe's second demographic transition”. Population bulletin 1.

Villeneuve-Gokalp Catherine. 2005. "Conséquences des ruptures familiales sur le départ des enfants", chapter 11 in Lefèvre, Filhon. 2005: 235-249. 
Toulemon et al.: France: High and stable fertility

\section{Appendix 1: Legal family benefits in France}

\begin{tabular}{|c|c|c|c|c|c|}
\hline Name & $\begin{array}{l}\text { Child age } \\
\text { eligibility } \\
\text { conditions }\end{array}$ & Means test & General rules & $\begin{array}{l}2006 \\
\text { monthly } \\
\text { individual amount } \\
\text { (euros) }\end{array}$ & $\begin{array}{l}\text { Total } 2005 \\
\text { amount } \\
\text { (millions of } \\
\text { euros) }\end{array}$ \\
\hline $\begin{array}{l}\text { Family allowance } \\
\text { ('allocations } \\
\text { familiales') }\end{array}$ & 0 to 20 & No & $\begin{array}{l}\text { Only dependent children are taken } \\
\text { into account: no benefit when the } \\
\text { child earns a minimum personal } \\
\text { income. Lump-sum benefit. No } \\
\text { benefit for the first child. Extra } \\
\text { benefit for children aged over } 11 \text { and } \\
\text { over } 16 .\end{array}$ & $\begin{array}{l}117 € \text { for two } \\
\text { children, } 150 € \\
\text { per extra child }\end{array}$ & 11952 \\
\hline Basic allocation & $\begin{array}{l}7^{\text {th }} \text { month of } \\
\text { pregnancy to } \\
3\end{array}$ & Yes & $\begin{array}{l}\text { First pillar of the 'prestation } \\
\text { d'accueil du jeune enfant' (PAJE). } \\
\text { Includes a 'one-shot' payment at } \\
\text { the } 7^{\text {th }} \text { month of pregnancy and a } \\
\text { monthly allowance from the birth } \\
\text { until the } 3^{\text {rd }} \text { birthday of the child. } \\
\text { Only } 10 \% \text { of families are } \\
\text { excluded by the means test. }\end{array}$ & $\begin{array}{l}841 € \text { ('one shot' } \\
\text { payment), } 186 € \\
\text { (monthly } \\
\text { allowance) }\end{array}$ & 3712 \\
\hline $\begin{array}{l}\text { Nursery benefit } \\
\text { ('complément de libre } \\
\text { choix du mode de } \\
\text { garde') }\end{array}$ & 0 to 6 & Partially & $\begin{array}{l}\text { Second pillar of the 'prestation } \\
\text { d'accueil du jeune enfant'. } \\
\text { Compensation for parents who entrust } \\
\text { their children to nurses, either at } \\
\text { home or at the nurse's home. The } \\
\text { benefit is paid per child for out-of- } \\
\text { home nursery, and per family for at- } \\
\text { home nursery. The amount of the } \\
\text { benefit decreases with family income } \\
\text { (three thresholds), and is half for } \\
\text { children aged } 3 \text { to } 6 \text {. }\end{array}$ & $\begin{array}{l}\text { from } 553 € \text { to } \\
763 € \text { for at- } \\
\text { home nursery; } \\
\text { from } 421 € \text { to } \\
632 € \text { for at- } \\
\text { home nursery } \\
\text { (children aged } \\
\text { under 3) }\end{array}$ & 3039 \\
\hline $\begin{array}{l}\text { Parental leave benefit } \\
\text { ('complément de libre } \\
\text { choix d'activité') }\end{array}$ & $\begin{array}{l}0 \text { to } 1 \\
\text { or } 0 \text { to } 3\end{array}$ & No & $\begin{array}{l}\text { Third pillar of the 'prestation } \\
\text { d'accueil du jeune enfant'. } \\
\text { Allowance for parents who stop } \\
\text { partially or totally working their } \\
\text { children of parity } 2 \text { and over. } \\
\text { Parents may choose between two } \\
\text { devices: a one-year high amount } \\
\text { benefit, or a three-year low } \\
\text { amount benefit. Adjusted for } \\
\text { parents who transfer from a full- } \\
\text { time to a part-time job. Recipients } \\
\text { of basic allowance get a reduced } \\
\text { amount of benefit. Subject to } \\
\text { conditions on past occupation. }\end{array}$ & $\begin{array}{l}\frac{1 \text { year: }}{578 € \text { (with basic }} \\
\text { allocation) } \\
746 € \text { (without) } \\
\underline{3 \text { years: }} \\
354 € \text { (with basic } \\
\text { allocation) } \\
522 € \text { (without) }\end{array}$ & 2739 \\
\hline
\end{tabular}




\section{Appendix 1: (Continued) Legal family benefits in France}

\begin{tabular}{|c|c|c|c|c|c|}
\hline Name & $\begin{array}{l}\text { Child age } \\
\text { eligibility } \\
\text { conditions }\end{array}$ & Means test & General rules & $\begin{array}{l}2006 \\
\text { monthly } \\
\text { individual amount } \\
\text { (euros) }\end{array}$ & $\begin{array}{l}\text { Total } 2005 \\
\text { amount } \\
\text { (millions of } \\
\text { euros) }\end{array}$ \\
\hline $\begin{array}{l}\text { Supplementary family } \\
\text { benefit } \\
\text { ('complément } \\
\text { familial) }\end{array}$ & 0 to 20 & Yes & $\begin{array}{l}\text { Supplementary allowance for } \\
\text { families with three children or } \\
\text { more. Cannot be held } \\
\text { concurrently with basic allocation. } \\
\text { Around } 20 \% \text { of families are } \\
\text { excluded by the means test. }\end{array}$ & $153 €$ & 1595 \\
\hline $\begin{array}{l}\text { New school year } \\
\text { benefit } \\
\text { ('allocation de rentrée } \\
\text { scolaire') }\end{array}$ & 6 to 17 & Yes & $\begin{array}{l}\text { 'One shot' allowance paid at the } \\
\text { start of the new school year to } \\
\text { families for each child going to } \\
\text { school. Around } 50 \% \text { of families } \\
\text { are excluded by the means test. }\end{array}$ & $268 €$ & 1381 \\
\hline $\begin{array}{l}\text { Familial support } \\
\text { benefit } \\
\text { ('allocation de soutien } \\
\text { familial') }\end{array}$ & 0 to 20 & No & $\begin{array}{l}\text { Allowance to persons who take } \\
\text { care of a child when one parent or } \\
\text { both are missing. In the case of a } \\
\text { divorced parent, it serves as an } \\
\text { advance on maintenance } \\
\text { allowance. }\end{array}$ & $\begin{array}{l}82 € \text { (one } \\
\text { missing parent), } \\
110 € \text { (two } \\
\text { missing parents) }\end{array}$ & 1071 \\
\hline $\begin{array}{l}\text { Lone-parent benefit } \\
\text { ('allocation de parent } \\
\text { isolé') }\end{array}$ & 0 to 3 & Yes & $\begin{array}{l}\text { Minimum income, e.g. differential } \\
\text { allowance: the amount is } \\
\text { calculated as the difference with } \\
\text { an upper threshold and all the } \\
\text { personal incomes of the single } \\
\text { parent. }\end{array}$ & $\begin{array}{l}736 € \text { for } 1 \text { child, } \\
184 € \text { per extra } \\
\text { child (maxi-mum } \\
\text { amount) }\end{array}$ & 963 \\
\hline $\begin{array}{l}\text { Father leave benefit } \\
\text { ('congé de paternité') }\end{array}$ & Birth & Partially & $\begin{array}{l}\text { Wage compensation for fathers } \\
\text { (with an income ceiling) who take } \\
\text { a maximum } 11 \text { days leave at the } \\
\text { birth of a child. }\end{array}$ & $\begin{array}{l}\text { Average daily } \\
\text { wage, with an } \\
\text { upper limit of } 69 \\
€ \text { a day }\end{array}$ & 200 \\
\hline
\end{tabular}

Source: CAUSSAT 2006 
Toulemon et al.: France: High and stable fertility 